\title{
Synthesis, stability, and reactivity of mesoionic carbene iridium dihydride complexes
}

\author{
Marta Olivares ${ }^{\mathrm{a}}$ and Martin Albrecht*a \\ ${ }^{a}$ Departement für Chemie und Biochemie, Universität Bern, Freiestrasse 3, CH-3012 Bern, \\ Switzerland \\ * to whom correspondence should be addressed: \\ E-mail: martin.albrecht@dcb.unibe.ch \\ Phone: +41316314644
}

Dedicated to Bob Morris in recognition of his pioneering work, in particular in hydrogen transfer chemistry 


\begin{abstract}
Pyridyl-triazolylidene ligands with variable donor properties were used as tunable ligands at a dihydride iridium(III) center. The straightforward synthesis of this type of ligand allows for an easy incorporation of electron donating substituents in different positions of the pyridine ring or different functional groups such as esters, alkoxy or aliphatic chains on the C4-position of the triazole heterocycle. The stability of these hydride metal systems allowed these complexes to be used as models for studying the influence of the ligand modifications on hydride reactivity. Spectroscopic analysis provided unambiguous structural assignment of the dihydride system. Modulation of the electronic properties of the wingtip substituents did not appreciably alter the reactivity of the hydrides. Reactivity studies using acids with a wide range of $\mathrm{p} K_{\mathrm{a}}$ values indicated a correlation between hydride reactivity and acidity and showed exclusive reactivity towards the less shielded hydride trans to the carbene carbon rather than the more shielded hydride trans to the pyridine ring, suggesting that the trans effect is more relevant in these reactions than the NMR spectroscopically deduced hydridic character.
\end{abstract}

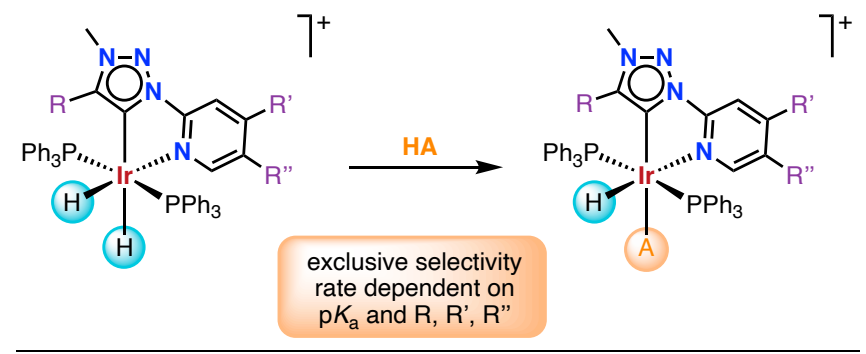




\section{Introduction}

Transition metal hydride complexes represent an important class of organometallic compounds because of their ability to function in a variety of catalytic and stoichiometric processes. ${ }^{1}$ They are involved, for example, in energy conversion or hydrogen storage applications. ${ }^{2,3}$ Metal hydride intermediates are also prevalent in reactions that involve $\mathrm{C}-\mathrm{H}$ bond activation, such as transfer hydrogenation, ${ }^{4,5,6,7}$ olefin isomerization, ${ }^{8,9}$ and $\mathrm{C}-\mathrm{H}$ functionalization. ${ }^{10,11,12,13}$

Understanding how changes in steric and electronic properties influence hydride transfer is of great importance in complex design in order to enhance stoichiometric and catalytic reactions involving metal hydrides. The term 'hydricity' is the most commonly used descriptor of hydride donor ability. The hydricity of a metal hydride therefore provides an experimentally measurable parameter that can help to predict the reactivity of a metal hydride. The two most common techniques for measuring the relative rates of hydride transfer to a reference substrate are NMR and UV-vis spectroscopy. Knowledge of cleaving metal hydride bonds enables the prediction of chemical reactivity, e.g. for bond-forming and bond-breaking events that occur in a catalytic reaction. Therefore, hydricity also connects fundamental bonding and reactivity studies with catalyst design principles and applications. ${ }^{14}$

Herein we introduce the facile reaction of triazolylidene precursor salts with a metal hydride precursor to obtain a new family of hydride iridium complexes. A major advantage of triazolylidene NHC ligands is their straightforward synthesis, which allows modifications to be introduced easily for fine-tuning the electronic and steric properties as a method to improve catalytic activity. We applied this concept through varying the substituents in different positions of the pyridyl ring and on the triazole heterocycle. All complexes are air-stable, which facilitates fundamental and reactivity studies that are considerably more difficult with more reactive hydride complexes or short-lived hydride intermediates. The stability of these iridium complexes is highly attractive for evaluating their behavior for the design of efficient catalysts and offers opportunities for materials science. ${ }^{15}$

Here, we have investigated the factors that favor hydride reactivity, such as electronic and steric variations of wingtip groups, trans influence/effects on the hydrides from the triazolylidene heterocycle or the pyridine ring, and the effect of acids with a wide range of $\mathrm{p} K_{\mathrm{a}}$ values. Remarkably and counterintuitively, in these complexes the more shielded hydride is demonstrated to be less reactive.

\section{Result and discussion}

\section{Synthesis and characterization of a series of dihydride iridium complexes with mesoionic} carbene ligands. Metalation of the known ${ }^{16,17}$ triazolium salts 1-3 was accomplished upon reaction with $\mathrm{IrH}_{5}\left(\mathrm{PPh}_{3}\right)_{2}$ in toluene at elevated temperature (Scheme 1), similar to related work 
with imidazolium salts. ${ }^{18}$ These conditions induced triazolium $\mathrm{C}-\mathrm{H}$ bond activation via cyclometalation and afforded complexes 4-6 as pale yellow solids. All complexes were formed within $24 \mathrm{~h}$. They were completely air- and moisture stable and were purified via standard column chromatography over silica in moderate yield and featured variable substituents on the triazolylidene unit $(\mathbf{4 a}, \mathbf{5}, \mathbf{6})$ and on the pyridyl site $(\mathbf{4 a}, \mathbf{4 b}, \mathbf{4 c})$.

Scheme 1. Synthesis of iridium complexes 4-6.

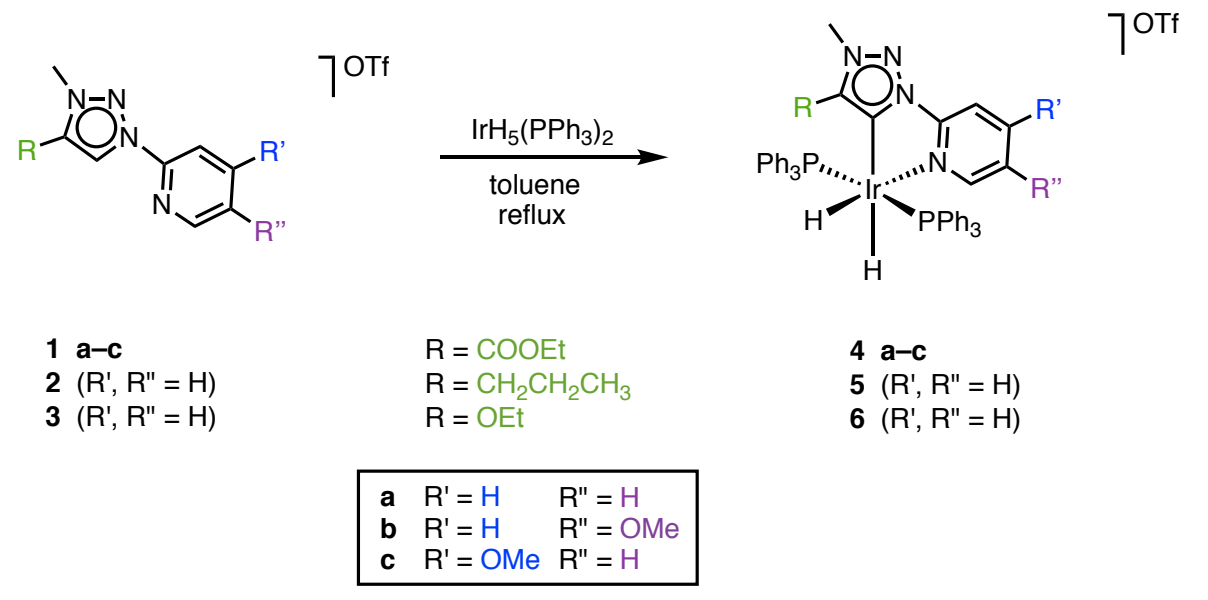

NMR characterization. All complexes were characterized by ${ }^{1} \mathrm{H},{ }^{13} \mathrm{C}$ and ${ }^{31} \mathrm{P} \quad \mathrm{NMR}$ spectroscopy, which are in good agreement with the proposed structures (Scheme 1). For all complexes, ${ }^{1} \mathrm{H}$ NMR spectroscopy confirms the coordination of two $\mathrm{PPh}_{3}$ ligands as the phenyl resonances integrate for $30 \mathrm{H}$. These phosphine nuclei are equivalent since only one singlet is observed in the ${ }^{31} \mathrm{P}$ NMR spectrum, resonating around $19( \pm 1) \mathrm{ppm}$. Moreover, all complexes show two inequivalent hydrides at high field resonances, both split into triplet of doublets by mutual coupling and coupling to two equivalent phosphorus nuclei. The $J_{\mathrm{HH}}$ of $5 \mathrm{~Hz}$ is typical of cis-positioned dihydrides, ${ }^{19}$ and the $J_{\mathrm{PH}}$ of $17-20 \mathrm{~Hz}$ is characteristic of a cis $\mathrm{M}\left(\mathrm{PR}_{3}\right) \mathrm{H}$ arrangement. ${ }^{19}$ The metal-bound hydride resonances are separated by almost $10 \mathrm{ppm}$ and appear around $\delta_{\mathrm{H}}=-11$ and $-20 \mathrm{ppm}$, reflecting the largely different influence of the triazolylidene and pyridine as trans ligands. So far, the assignment of this type of dihydride systems has been controversial in the literature. ${ }^{18,20}$ Here, NOEs were detected between the hydride at $-20 \mathrm{ppm}$ and the $\mathrm{CH}_{2}$ of the $-\mathrm{OEt}$ group $\left(\delta_{\mathrm{H}}=3.8 \mathrm{ppm}\right)$ of complex $\mathbf{6}$, and additionally between the hydride at $-11 \mathrm{ppm}$ and the pyridyl $\mathrm{C}^{6}-\mathrm{H}$ proton at around $8 \mathrm{ppm}$ (Figure 1). These NOE experiments indicate therefore that the higher field hydride at $-20 \mathrm{ppm}$ is cis to the triazolylidene (denoted as $\mathrm{H}_{\text {cis }}$ ) moiety and the lower field hydride ( $\left.-11 \mathrm{ppm}\right)$ is $c$ is to the pyridyl ligand (denoted as $\mathrm{H}_{\text {trans }}$ ). Similar NOE experiments were also run with complexes $\mathbf{4 b}$ and $\mathbf{5}$, and the results were in line with the assignments obtained for complex 6 (Fig. S1, S2). Notably, this experimental assignment 
is counterintuitive when considering the higher trans influence of the carbene vs pyridine, and indicates that the NMR chemical shifts are not correctly reflecting hydricity.

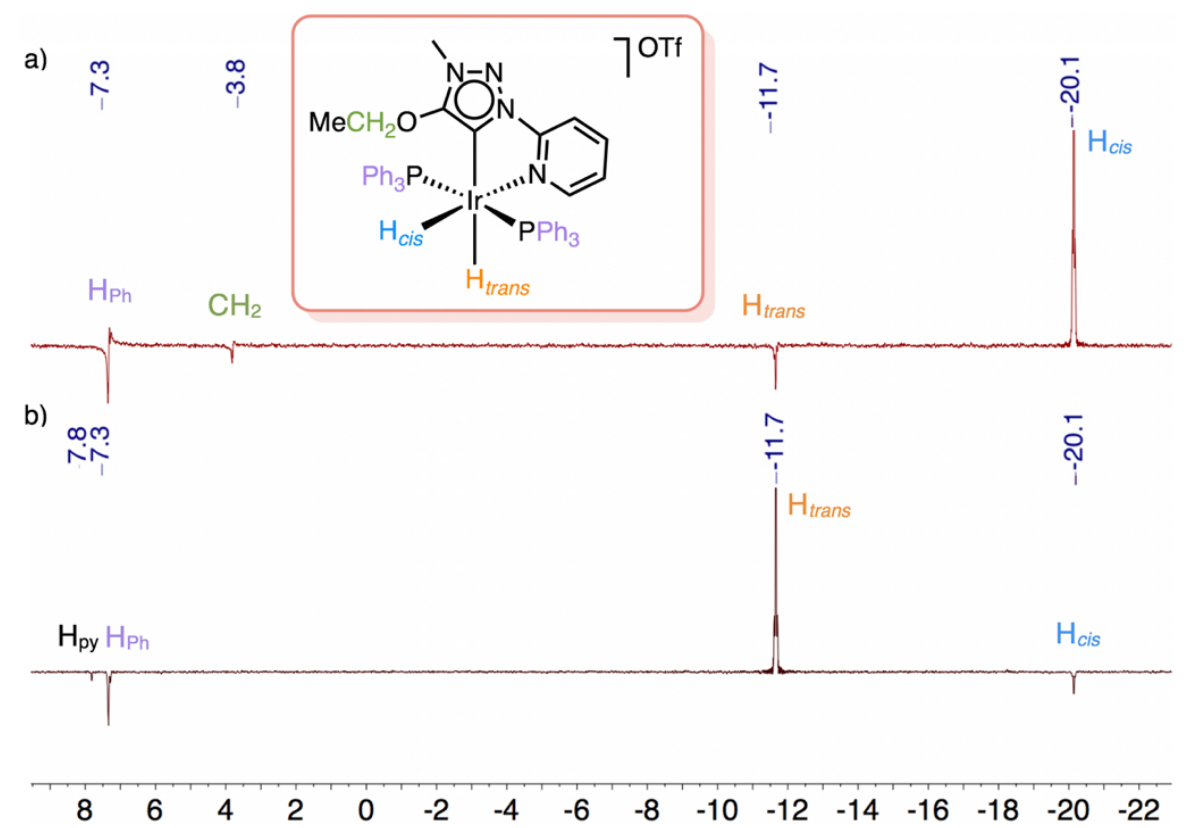

Figure 1. NOE experiment $\left(\mathrm{CDCl}_{3}, 400 \mathrm{MHz}, 298 \mathrm{~K}\right)$ for assignment of hydride resonances using complex 6. NOE correlations obtained from selective irradiation of a) the cis hydride resonance at $-20 \mathrm{ppm}$ and b) the trans hydride resonance at -11 ppm (trans and cis relative to the carbene ligand).

The influence of different electron donating/withdrawing substituent $\mathrm{R}$ on the triazolylidene donor site $(\mathrm{R}=-\mathrm{COOEt},-n \mathrm{Pr}$, or $-\mathrm{OEt}$, Figure 2$)$ is evident when comparing complexes 4a, 5 and 6 containing the same pyridine moiety (Table 1 ). According to ${ }^{13} \mathrm{C}$ NMR analysis, the chemical shifts of the carbenic carbon, the $\mathrm{N}-\mathrm{CH}_{3}$ and the $\mathrm{C}_{\mathrm{trz}}-\mathrm{R}$ for complexes $4 \mathbf{a}$ and $\mathbf{6}$ significantly differ, while the resonance frequencies of complex $\mathbf{5}$ always stay in between. Thus, the carbenic carbon significantly appears at lower field in complex 6 with an electron donating OEt substituent compared to the presence of an electron-withdrawing-COOEt group in complex 4a $\left(\delta_{\mathrm{C}}=175\right.$ and $146 \mathrm{ppm}$, respectively). A similar chemical shift divergence is also observed for the $\mathrm{N}-\mathrm{CH}_{3}$ group, although less pronounced ( $\delta_{\mathrm{C}}=42.2$ and $35 \mathrm{ppm}$, respectively). However, the quaternary carbon directly bound to the variable substituent $\left(\mathrm{C}_{\mathrm{trz}}-\mathrm{R}\right)$ is oppositely polarized and hence, appears at lower field in complex $6\left(\mathrm{R}=\mathrm{OEt}, \delta_{\mathrm{C}}=157.6 \mathrm{ppm}\right)$ than in complex $4 \mathbf{a}(\mathrm{R}=$ COOEt, $\delta_{\mathrm{C}}=137.2 \mathrm{ppm}$ ). The strong influence of the triazolylidene substituent is also supported by a shift of the $\mathrm{N}-\mathrm{CH}_{3}$ group in the ${ }^{1} \mathrm{H}$ NMR spectra which is increasingly shielded with stronger donating substituents $\mathrm{R}$ from $\delta_{\mathrm{H}}=4.12(\mathrm{R}=\mathrm{COOEt})$ to $3.90(\mathrm{R}=n \operatorname{Pr})$ and $3.70(\mathrm{R}=\mathrm{OEt})$. Remarkably, the chemical shift of the hydride trans to pyridine shows a correlation with the electronic nature of the triazolylidene substituents. A higher field shift was noted upon increasing 
the electron donating character of the substituent $\mathrm{R}$ along the series with $\delta_{\mathrm{H}}=-19.85(\mathbf{4 a}, \mathrm{R}=$ COOEt $)>-20.04(\mathbf{5}, \mathrm{R}=n \operatorname{Pr})>-20.16 \mathrm{ppm}(\mathbf{6}, \mathrm{R}=\mathrm{OEt})$. Notably, the influence is weaker for the hydride $(\Delta \delta=0.31 \mathrm{ppm})$ than for the $\mathrm{NCH}_{3}$ group $(\Delta \delta=0.42 \mathrm{ppm})$. Moreover, no such trend was observed for the chemical shift of the hydride trans to the carbene carbon and the phosphorus resonances. These resonances appear further downfield for complex $5\left(\delta_{\mathrm{H}}=-10.95, \delta_{\mathrm{P}}=19.7\right)$ than for complex $4 \mathbf{a}\left(\delta_{\mathrm{H}}=-11.08, \delta_{\mathrm{P}}=19.5\right)$ and are most upfield for complex $\mathbf{6}\left(\delta_{\mathrm{H}}=-11.52, \delta_{\mathrm{P}}\right.$ $=18.9)$. This sequence does not reflect the electron-donating nature of the triazolylidene substituent and counteracts the general principle that the trans influence is much stronger than the cis influence. Possibly, other factors such as steric or polarity effects, are relevant for defining the shift of the resonances of these nuclei.

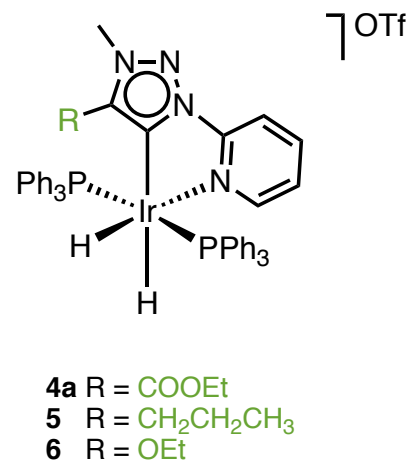

Figure 2. Complexes 4a, 5 and $\mathbf{6}$ with different modifications on the triazole heterocycle.

Table 1. Selected chemical shifts from ${ }^{1} \mathrm{H},{ }^{13} \mathrm{C}$ and ${ }^{31} \mathrm{P}$ NMR analysis for complexes $\mathbf{4 a}-\mathbf{c}, \mathbf{5}$ and $\mathbf{6} .{ }^{a}$

\begin{tabular}{llllllllc}
\hline Complex & \multicolumn{5}{c}{${ }^{1} \mathrm{H}$ NMR $(\mathrm{ppm})^{b}$} & \multicolumn{5}{c}{${ }^{13} \mathrm{C} \mathrm{NMR}(\mathrm{ppm})$} & ${ }^{31} \mathrm{P} N \mathrm{NR}(\mathrm{ppm})$ \\
\hline & $\mathrm{NCH}_{3}$ & $\mathrm{H}_{\text {trans }}$ & $\mathrm{H}_{\text {cis }}$ & $\mathrm{C}_{\mathrm{tr} z}-\mathrm{Ir}$ & $\mathrm{NCH}_{3}$ & $\mathrm{C}_{\mathrm{tr} z}-\mathrm{R}$ & $\mathrm{C}_{\mathrm{py}}-\mathrm{N}_{\mathrm{trz}}$ & \\
$\mathbf{4 a}$ & 4.12 & -11.08 & -19.85 & 175.0 & 42.2 & 137.2 & 150.6 & 19.5 \\
$\mathbf{4 b}$ & 4.09 & -11.27 & -19.95 & 173.0 & 42.0 & 137.1 & 144.2 & 20.0 \\
$\mathbf{4 c}$ & 4.09 & -11.14 & -20.11 & 175.6 & 42.2 & 137.2 & 152.1 & 19.7 \\
$\mathbf{5}$ & 3.90 & -10.95 & -20.04 & 165.0 & 38.0 & 148.2 & 151.5 & 19.7 \\
$\mathbf{6}$ & 3.70 & -11.52 & -20.16 & 146.0 & 35.0 & 157.6 & 151.3 & 18.9 \\
\hline
\end{tabular}

$\bar{a}$ in $\mathrm{CD}_{3} \mathrm{CN}$ at $400\left({ }^{1} \mathrm{H}\right), 100\left({ }^{13} \mathrm{C}\right)$ and $121\left({ }^{31} \mathrm{P}\right) \mathrm{MHz} ;{ }^{b}$ trans and cis relative to the triazolylidene $\mathrm{C}_{\text {trz. }}$.

An analogous comparison of the spectroscopic properties of complexes $4 \mathbf{4 a - c}$ allows for evaluating the influence of the substituents on the pyridine heterocycle (Table 1). According to ${ }^{13} \mathrm{C}$ NMR spectroscopy, the chemical shift of the carbenic carbon $\left(\mathrm{Ir}-\mathrm{C}_{\mathrm{trz}}\right.$ ) is similar for complexes $\mathbf{4 a}$ and $\mathbf{4 c}$ at 175.3(3) ppm, whereas it is slightly upfield shifted in complex $\mathbf{4 b}\left(\delta_{\mathrm{C}}=173 \mathrm{ppm}\right)$. The quaternary pyridyl carbon bound to the triazole nitrogen $\left(\mathrm{C}_{\mathrm{py}}-\mathrm{N}_{\mathrm{trz}}\right)$ also shifts remarkably $\left(\delta_{\mathrm{C}}=144.2 \mathrm{ppm}\right.$ for complex $\mathbf{4 b} v s .150 .6 \mathrm{ppm}$ for complex $\mathbf{4 a}$ and $152.1 \mathrm{ppm}$ for complex $\left.\mathbf{4 c}\right)$. 
The upfield shifts of the $\mathrm{C}_{\mathrm{trz}}-\mathrm{Ir}$ and $\mathrm{C}_{\mathrm{py}}-\mathrm{N}_{\mathrm{trz}}$ nuclei in complex $\mathbf{4 b}$ are related to the para position of the-OMe group relative to the quaternary $\mathrm{C}_{\mathrm{py}}$. In contrast, the meta effect of the-OMe group in complex $4 \mathbf{c}$ induces a downfield shift to $\delta_{\mathrm{C}}=152.1 \mathrm{ppm}$ of this quaternary carbon.

The introduction of a-OMe substituent, either para or meta to the pyridyl nitrogen also shifts the two hydride resonances to higher field compared to the unsubstituted pyridyl system in complex 4a. The changes are relatively small, however $\left(\Delta \delta 0.19 \mathrm{ppm}\right.$ for $\mathrm{H}_{\text {trans }}$ and 0.26 for $\left.\mathrm{H}_{c i s}\right)$. The methoxy substituent para to the pyridyl nitrogen in $\mathbf{4} \mathbf{c}$ exerts a stronger shift of the hydride trans to the pyridyl nitrogen $\left(\mathrm{H}_{c i s} \delta_{\mathrm{H}}=-20.11 v s .-19.85\right.$ for $\left.4 \mathbf{a}\right)$, than $\mathrm{H}_{\text {trans }}\left(\delta_{\mathrm{H}}=-11.14 v s .-11.08\right)$. In contrast, positioning the -OMe substituent meta to the pyridyl nitrogen (4b) affects the hydride trans to the carbene more $\left(\delta_{\mathrm{H}}=-11.27\right.$ vs. -11.08$)$, while the hydride trans to the pyridyl $\left(\mathrm{H}_{c i s}\right)$ is less affected $\left(\delta_{\mathrm{H}}=-19.95 v s\right.$. -19.85$)$. Albeit small, these chemical shifts of the hydride correlate with the Hammett meta and para effects of the -OMe group $\left(\sigma_{\text {meta }}=+0.12, \sigma_{\text {para }}=-0.27\right)$. Accordingly, the hydride trans to pyridine is directly influenced by the para effect of the OMe substituent in complex $\mathbf{4 c}\left(\sigma_{\text {para }}=-0.27\right)$ and shows the highest shift of the series $\left(\delta_{\mathrm{H}(c i s)}=-20.11\right)$. A similar behavior of the OMe substituent can be surmised for complex $\mathbf{4 b}$, which is located in para position of the triazolylidene ring, and hence, the hydride trans to carbene carbon shows the highest shift of the series $\left(\delta_{\mathrm{H}(\text { trans })}=-11.27\right)$.

Structural characterization in the solid state. The structures of complexes $\mathbf{4 a - c}, \mathbf{5}$ and $\mathbf{6}$ were determined in the solid state by single crystal X-ray diffraction analyses and unambiguously confirmed the connectivity pattern deduced from NMR spectroscopy (Figure 3). All complexes feature an octahedral iridium center with two mutually trans positioned phosphines. ${ }^{18,20} \mathrm{The} \mathrm{Ir}-$ $\mathrm{H}$ distances were refined with a constrained $\mathrm{Ir}-\mathrm{H}$ distance to avoid divergence. Bond lengths and angles (Table 2) are generally within expectation and similar to related imidazolylidene complexes. ${ }^{18,20}$ It is worth noting that the presence of the -OMe substituent on the pyridine induces an elongation of the $\mathrm{Ir}-\mathrm{N}_{\mathrm{py}}$ bond from 2.153(2) $\AA$ in $\mathbf{4 a}$ to 2.187( \pm 0.006$) \AA$ in complexes 4b and 4c. Moreover, the phosphines are considerably more linear in complex 6 containing an OEt substituent on the triazolylidene unit $\left(\mathrm{P} 1-\mathrm{Ir}-\mathrm{P} 2=172^{\circ}\right)$ than in the other complexes investigated here $\left(\mathrm{P} 1-\mathrm{Ir}-\mathrm{P} 2=165( \pm 1)^{\circ}\right)$ or reported in the literature $\left(\mathrm{P} 1-\mathrm{Ir}-\mathrm{P} 2=159^{\circ}\right){ }^{20}$

The ester group in complexes $\mathbf{4 a - c}$ is essentially co-planar with the triazolylidene heterocycle. In this series the $C, N$-bidentate ligand is wagging and variations in the $\mathrm{Ir}-\mathrm{C}_{\mathrm{trz}}$ bond length are compensated by a reciprocal modulation of the Ir- $\mathrm{N}_{\mathrm{py}}$ distance. For example, complex $4 \mathbf{a}$ has the longest Ir- $\mathrm{C}_{\mathrm{trz}}$ bond and the shortest Ir- $\mathrm{N}_{\mathrm{py}}$ bond of the series, while complex $\mathbf{4 b}$ bearing $-\mathrm{OMe}$ meta to the $\mathrm{N}_{\mathrm{py}}$ features the longest Ir- $\mathrm{N}_{\mathrm{py}}$ and the shortest $\mathrm{Ir}-\mathrm{C}_{\mathrm{trz}}$ bond of the three complexes 4a-c (Figure S3). Interestingly, the variation of $\mathrm{Ir}-\mathrm{C}_{\mathrm{trz}}$ bond length correlates well with the ${ }^{1} \mathrm{H}$ NMR chemical shift of the hydride trans to the $\mathrm{Ir}-\mathrm{C}_{\text {trz }}$ bond. Thus, complex $\mathbf{4 b}$ has the shortest 
Ir- $\mathrm{C}_{\text {trz }}$ distance (2.050(5) $\AA$ ) and the most hydridic hydride trans to the carbene carbon of the $\mathbf{4 a}-$ c series $\left(\delta_{\mathrm{H}}=-11.27\right)$. Complex $4 \mathbf{c}$ is intermediate $\left(\mathrm{Ir}-\mathrm{C}_{\mathrm{trz}}=2.059(6) \AA, \delta_{\mathrm{H}}=-11.14\right)$ and complex 4a with the longest Ir- $\mathrm{C}_{\text {trz }}$ bond (2.075(3) $\AA$ ) shows the least hydridic trans hydride of the series $\left(\delta_{\mathrm{H}}=-11.08\right)$. The direct response of both the $\mathrm{Ir}-\mathrm{C}_{\text {trz }}$ bond length and the $\mathrm{H}_{\text {trans }}$ chemical shift upon introduction of electron donating substituents on the pyridine suggest a rational tunability of the electronic configuration of the metal center and the hydricity of the iridium-bound hydrogen. ${ }^{21}$

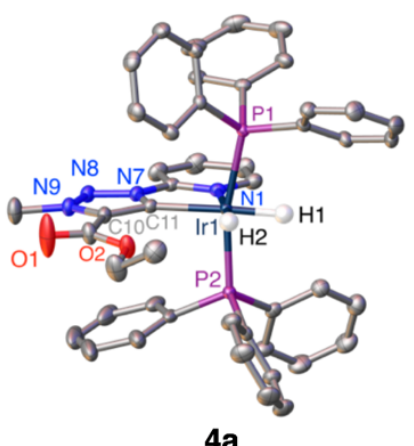

$4 \mathbf{a}$

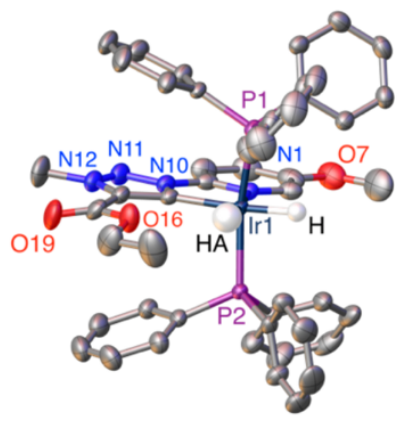

4b

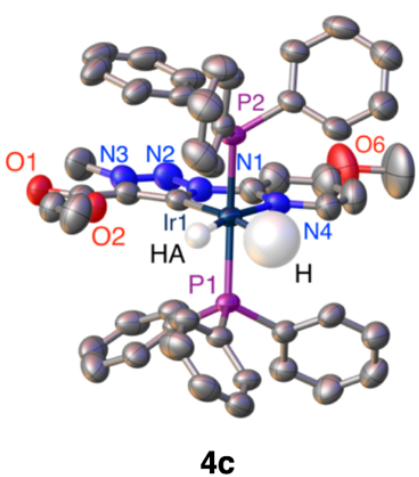

4c
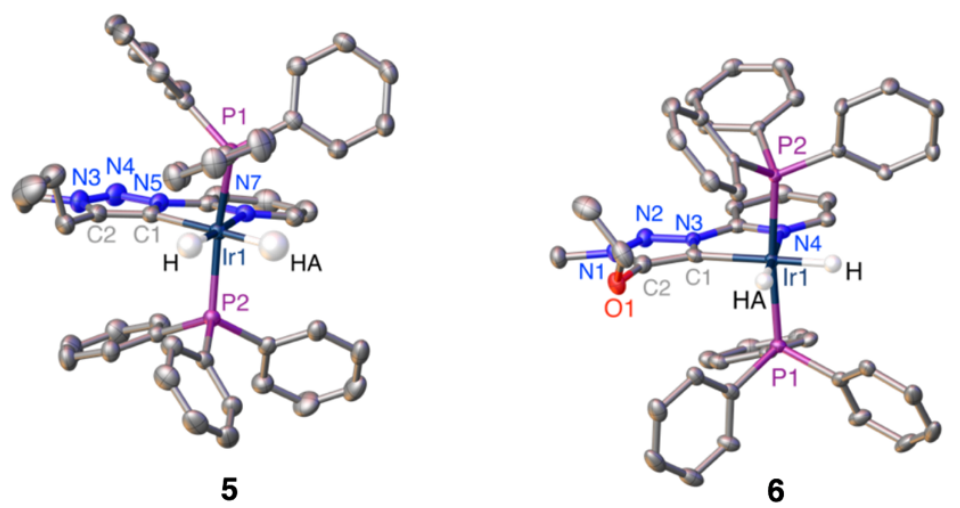

Figure 3. ORTEP plots for complexes $4 \mathbf{a}-\mathbf{c}, \mathbf{5}$ and $\mathbf{6}$ (50\% probability, non-coordinating anions and co-crystallized solvent molecules omitted for clarity). Only the metal bound hydrogens (calculated positions) are shown.

Table 2. Selected bond lengths $(\AA)$ and angles $\left(^{\circ}\right)$ for complexes $\mathbf{4 a}-\mathbf{c}, \mathbf{5}$ and $\mathbf{6}$.

\begin{tabular}{|c|c|c|c|c|c|}
\hline Complex & $4 a$ & $4 b$ & $4 c$ & 5 & 6 \\
\hline Ir-P1 & $2.2987(7)$ & $2.2937(14)$ & $2.2936(17)$ & $2.2960(6)$ & $2.2983(8)$ \\
\hline $\mathrm{Ir}-\mathrm{P} 2$ & $2.3048(7)$ & $2.2846(13)$ & $2.2874(17)$ & $2.2998(6)$ & $2.3115(7)$ \\
\hline $\mathrm{Ir}-\mathrm{N}_{\mathrm{py}}$ & $2.153(2)$ & $2.193(5)$ & $2.180(7)$ & $2.1918(18)$ & 2.177(3) \\
\hline $\mathrm{Ir}-\mathrm{C}_{\mathrm{trz}}$ & $2.075(3)$ & $2.050(5)$ & $2.059(6)$ & $2.054(2)$ & $2.095(3)$ \\
\hline $\mathrm{C}_{\mathrm{tr} z}-\mathrm{C}_{\mathrm{trz}}$ & $1.394(4)$ & $1.389(8)$ & $1.383(9)$ & $1.385(3)$ & $1.380(5)$ \\
\hline $\mathrm{C}_{\mathrm{tr} z}-\mathrm{Ir}-\mathrm{N}_{\mathrm{py}}$ & $77.699(10)$ & $77.662(2)$ & $77.589(2)$ & $77.090(8)$ & $77.093(11)$ \\
\hline $\mathrm{P} 1-\mathrm{Ir}-\mathrm{P} 2$ & $165.752(2)$ & $164.466(5)$ & $165.850(7)$ & $165.768(2)$ & $172.563(3)$ \\
\hline
\end{tabular}


Kinetic hydricity of complex 4a upon reaction with different acids. While many iridium(III) dihydride systems are known, ${ }^{22}$ only a much smaller number have the two hydrides in chemically inequivalent cis positions that have the potential to impart unique reactivity. ${ }^{23,24}$ Due to the large inequivalence of the two hydrides in the iridium complexes 4-6, the hydricity of complex 4a was evaluated upon reaction with a variety of acids with different $\mathrm{p} K_{\mathrm{a}}$ values (Scheme 2). These experiments were generally performed using an excess of the corresponding acid (200 eq) in $\mathrm{CDCl}_{3}$ solution and using complex $\mathbf{4 a}$ as the hydride source. Protonation involved selectively the hydride trans to the triazolylidene ligand and afforded the monohydride complexes $\mathbf{7 - 1 0}$. The residual hydride trans to the pyridyl ligand appeared as a triplet at $\delta_{\mathrm{H}}=-16.8( \pm 0.4) \mathrm{ppm}$ in complexes 7-10, which corresponds to a downfield shift compared to the starting material by about 4 ppm (see also X-ray structures below). Diagnostically, also the ${ }^{31} \mathrm{P}$ NMR resonance shifts upfield from about $19 \mathrm{ppm}$ in the dihydride complexes to $6.5( \pm 1) \mathrm{ppm}$ in the monohydride complexes 8-10. The resonance is shifted to even higher field when phosphoric acid was used with $\delta_{\mathrm{P}}=0$ ppm for complex 7 .

Scheme 2. Reaction of complex $4 \mathrm{a}$ with a variety of acids with different $\mathrm{p} K \mathrm{a}$.

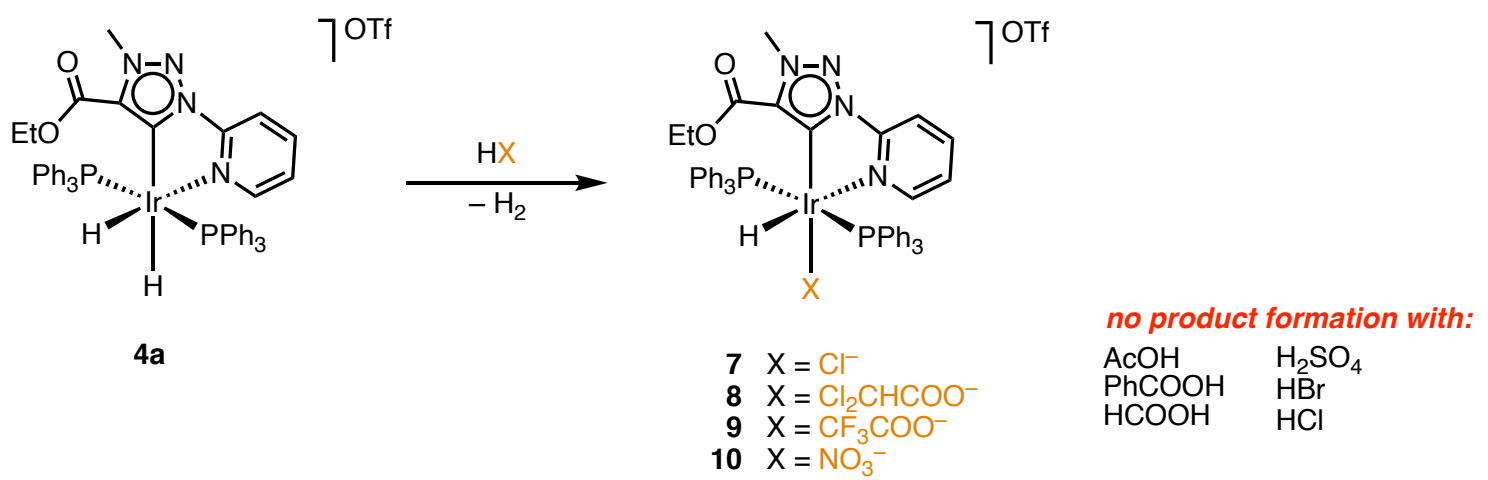

No reaction of $4 \mathbf{a}$ took place under the standard conditions upon exposing this complex to weak acids such as formic acid $\left(\mathrm{p} K_{\mathrm{a}}=3.75\right)$, benzoic acid $\left(\mathrm{p} K_{\mathrm{a}}=4.20\right)$ or acetic acid $\left(\mathrm{p} K_{\mathrm{a}}=4.75\right)$ neither at room temperature nor at elevated temperature $\left(70{ }^{\circ} \mathrm{C}\right.$ in $\mathrm{CDCl}_{3} ; \mathrm{p} K_{\mathrm{a}}$ values in water, though a similar relative acidity trend is assumed in $\mathrm{CDCl}_{3}$ ). Complete disappearance of the hydride resonance was observed with phosphoric acid $\left(\mathrm{p} K_{\mathrm{a}}=2.12\right)$ after $38 \mathrm{~h}$ at $70{ }^{\circ} \mathrm{C}$ as well as with dichloroacetic acid $\left(\mathrm{p} K_{\mathrm{a}}=1.35\right.$, full conversion after $\left.20 \mathrm{~h}\right)$. With oxalic acid $\left(\mathrm{p} K_{\mathrm{a}}=1.21\right)$ the reaction ceased after about $20 \%$ conversion, suggesting some undesired side-reactions of this acid. Complex 4a reacted significantly faster with trifluoroacetic acid $\left(\mathrm{p} K_{\mathrm{a}}=0.25\right)$ and was fully consumed after 5 min already at room temperature. With stronger acids, divergent reactivity patterns were observed (see SI for details).

It is worth noting that the electronically more deshielded hydride at $\delta_{\mathrm{H}}=-11 \mathrm{ppm}$ and trans to the carbene is reacting with the acid as it disappears over time or instantly depending on the acid 
used, and not the hydrogen trans to the pyridyl unit that is more hydridic according to its NMR chemical shift $\left(\delta_{\mathrm{H}}=-20 \mathrm{ppm}\right)$. This hydride however changes multiplicity from a doublet of triplets to a simple triplet and disappears over time with concomitant growing of the signal around $\delta_{\mathrm{H}}=-17 \mathrm{ppm}$ indicative of the new monohydride complexes. The high selectivity of the reaction indicates that the trans effect (carbene $>$ pyridine) is more relevant than the hydricity deduced from NMR spectroscopy, in agreement with kinetic rather than thermodynamic hydricity governing the reactivity pathway. ${ }^{14,25,26}$ Moreover, the reactivity of the hydride is correlated to the acid strength only within a limited $\mathrm{p} K_{\mathrm{a}}$ window in the $0-5$ range. With stronger acids the reactivity is highly diverging and may involve the reaction of both hydrides and maybe reactions including reductive elimination and oxidative addition cycles. An unaccounted outlier is nitric acid ( $\mathrm{p} K_{\mathrm{a}}=$ $-1.4)$ which needs elevated temperature to selectively form one product, while trifluoroacetic acid $\left(\mathrm{p} K_{\mathrm{a}}=0.25\right)$ reacts instantly at room temperature. ${ }^{27}$

The striking difference of the two hydrides in complexes $4 \mathbf{a}$ is remarkable, especially when considering that related complexes with inequivalent cis dihydride ligands showed either rapid exchange in the presence upon protonation, or the reactivity of the hydrides is not known. ${ }^{23} \mathrm{~A}$ complex with a $C, N$-bidentate benzoquinone trans to the two hydrides showed exclusive reactivity of one hydride, though only when a directing ammonium group was present in close proximity to the hydride trans to the aryl donor site. ${ }^{24}$

No reactivity of complex $4 \mathbf{a}$ towards peroxides $\left(\mathrm{H}_{2} \mathrm{O}_{2}\right.$ and $\left.{ }^{t} \mathrm{BuOOH}\right)$ was observed. Although peroxides in presence of $\mathrm{CuI}$ reacted with complex $4 \mathbf{a}$ at room temperature within 5 min to give the iodide complex 11 (Scheme 3). This iodide complex was characterized by a high-field phosphine resonance $\left(\delta_{\mathrm{P}}=-4.7 \mathrm{ppm}\right)$ and a hydride resonance that is less downfield $\left(\delta_{\mathrm{H}}=-17.93\right.$ ppm) than the hydrides of complexes 8-10 containing oxo acid fragments. Similar reactivity patterns were observed also when complex $4 \mathbf{a}$ was reacted with meta-chloroperoxybenzoic acid ( $m$ CPBA), which formed the benzoate complex 12 at room temperature within 10 min (Scheme $3)$. Both products where further identified by a single crystal X-ray diffraction analysis.

Scheme 3. Synthesis of complexes 11 and 12 from complex $4 a$ and ORTEP plots for both complexes (50\% probability, $\mathrm{H}$ atoms except hydrides, non-coordinating anions and co-crystallized solvent omitted for clarity).

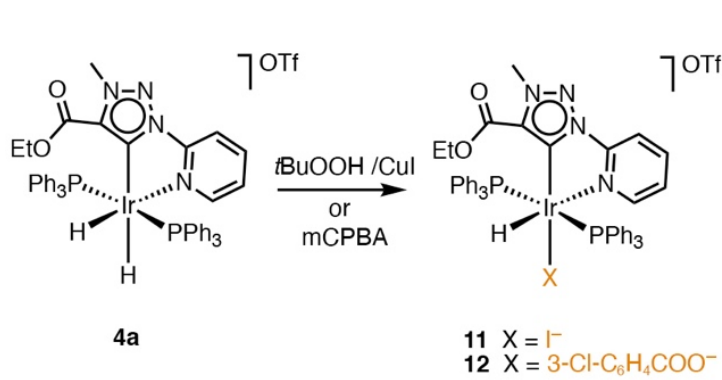

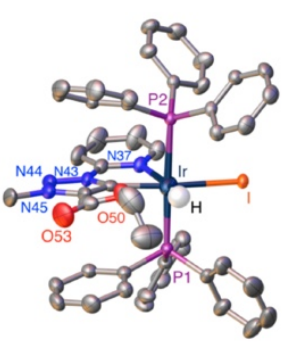

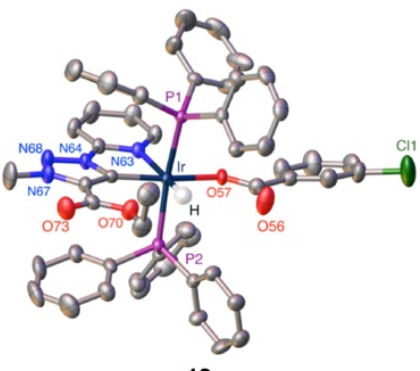


Hydricity of complexes 4-6. More detailed insights into the reactivity of these complexes were obtained by kinetic measurements using dichloroacetic acid. The addition of an excess of this acid (200 molar equivalents, pseudo-first order conditions) to a solution of the metal complexes resulted in the clean formation of the corresponding monohydride complexes 8,13 and 14 (Scheme 4).

Scheme 4. Reaction of complex 4-6 with dichloroacetic acid.
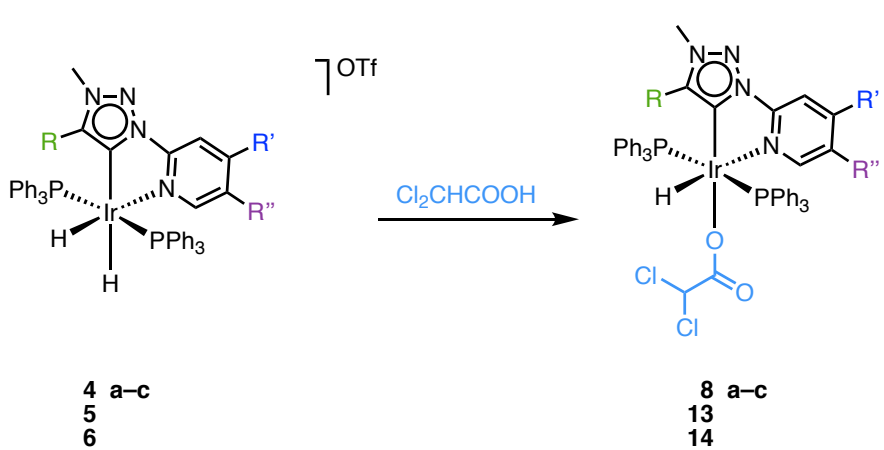

$7^{\mathrm{OTf}}$

6

$$
r^{8}{ }^{a-c}
$$

The reactivity of the different complexes was studied by NMR spectroscopic monitoring of the disappearance of the dihydride complexes 4-6 $\left(\delta_{\mathrm{H}}-20, \delta_{\mathrm{P}} 19\right)$ and the gradual formation of the monohydride product around $\left(\delta_{\mathrm{H}}-16, \delta_{\mathrm{P}} 6\right)$ using a capillary containing a known ruthenium(II) phosphine hydride complex as internal standard. We noted that the hydride trans to the carbene carbon resonance rapidly disappears after adding dichloroacetic acid, probably due to isotope exchange, since all other ${ }^{1} \mathrm{H}$ NMR signals are preserved without any change of resonance frequency. Both the ${ }^{1} \mathrm{H}$ and the ${ }^{31} \mathrm{P}$ NMR probes consistently indicate that complexes $\mathbf{4 c}$ and $\mathbf{5}$ are the most reactive complexes with dichloroacetic acid at $70{ }^{\circ} \mathrm{C}$ and reach full conversion within 5 h (Figure 7a, Fig. S4). Logarithmic plots of the concentration of the dihydride complex versus time showed a linear correlation, indicating (pseudo-)first-order kinetics with $k_{\mathrm{obs}}=183( \pm 17) \times$ $10^{-6} \mathrm{~s}^{-1}$ and $193( \pm 7) \times 10^{-6} \mathrm{~s}^{-1}$ for $\mathbf{4 c}$ and $\mathbf{5}$, respectively (Fig. 7b). Complex $\mathbf{4 a}$ is less reactive and needs $20 \mathrm{~h}$ to fully transform the dihydride complex $\left(k_{\mathrm{obs}}=56( \pm 3) \times 10^{-6} \mathrm{~s}^{-1}\right)$. In contrast, complexes $4 \mathbf{b}$ and 6 were not fully converted and reached about $75 \%$ conversion after $20 \mathrm{~h}$ with the lowest observed rates of this series, $k_{\mathrm{obs}}=15( \pm 4)$ and $25( \pm 6) \times 10^{-6} \mathrm{~s}^{-1}$, respectively. ${ }^{28}$ It is interesting to note that these rates do not correlate with the electronic impact of the triazolylidene ligand. Thus, the alkyl-substituted triazolylidene in complex $\mathbf{5}$ imparts almost an order of magnitude higher reactivity towards the acid than complex 6 with an electron-donating alkoxy substituent, while the analogous complex 4a with an electron-withdrawing ester unit has intermediate reactivity. In contrast, the pyridyl substitution appears more rational with para-OMe substitution with a negative Hammett parameter $\left(\sigma_{\mathrm{p}}=-0.27, \mathbf{4 c}\right)$ inducing faster rates than no 
substituent $(\sigma=0, \mathbf{4 a})$, while the meta-OMe system is the slowest $\left(\sigma_{\mathrm{m}}=+0.12, \mathbf{4 b}\right)$. This trend is remarkable, since the pyridyl substituent is cis to the supposedly most reactive hydride.

Moreover, the hydricity deduced by ${ }^{1} \mathrm{H}$ NMR spectroscopy is not correlated to the reactivity rates (Fig. S5). For example, complex 6 containing the most hydridic hydride trans to the carbene carbon $\left(\delta_{\mathrm{H}}-11.52\right)$ has a very low reaction rate $\left(k_{\mathrm{obs}}=25 \times 10^{-6} \mathrm{~s}^{-1}\right)$, whereas the fastest reacting complexes, $\mathbf{4 c}$ and $\mathbf{5}$, feature hydrides with intermediate or lowest field chemical shifts in this series $\left(\delta_{\mathrm{H}}-11.14\right.$ and -10.95 , respectively). This work therefore indicates that the NMR-deduced hydricity is not a valuable proxy for predicting the reactivity in these dihydride complexes 4-6 and that instead other factors may be relevant for imparting high reactivity, such as heteroatominduced hydride or proton stabilization.

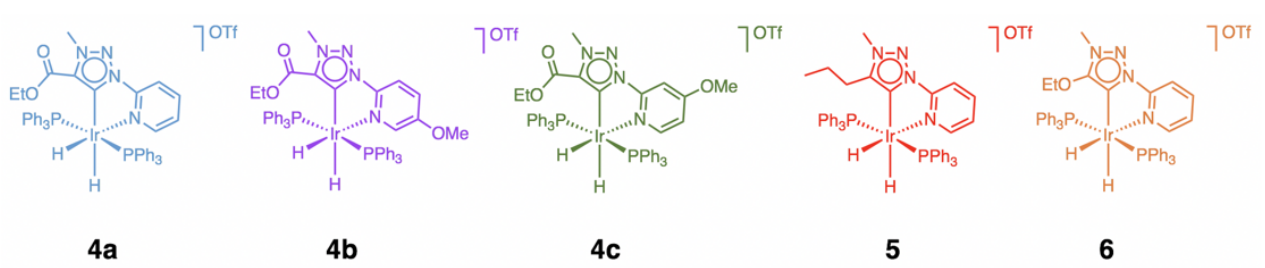

a)

b)
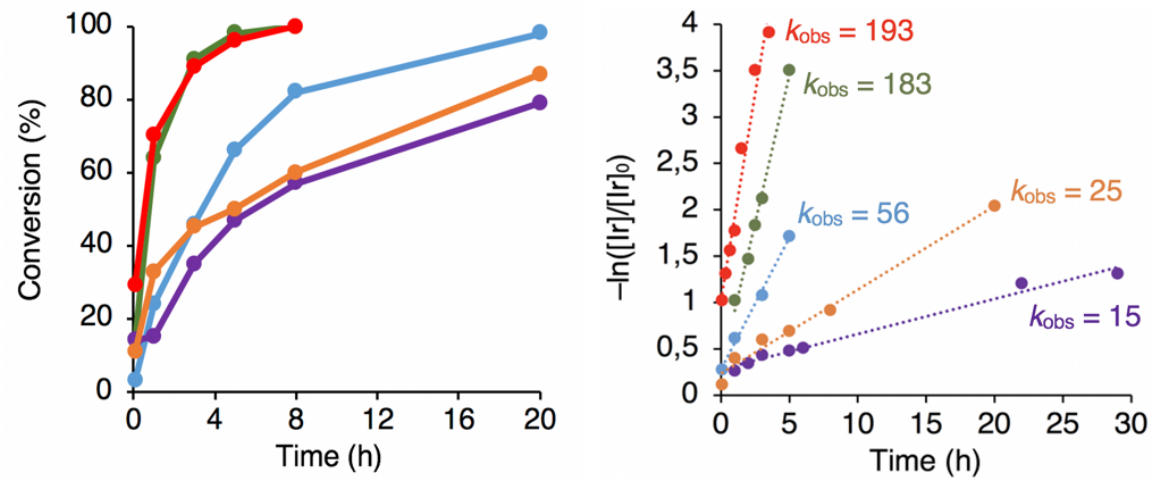

Figure 4. For complexes 4a (blue), $4 \mathbf{b}$ (purple), $4 \mathbf{c}$ (green), 5 (red) and 6 (orange). a) Time-dependent conversion profile for the reaction of each complex with $\mathrm{Cl}_{2} \mathrm{CHCOOH}$. Conditions: $\mathrm{Cl}_{2} \mathrm{CHCOOH}(200 \mathrm{eq}$ ), [Ir] $(4 \mu \mathrm{mol}), \mathrm{CDCl}_{3}(0.4 \mathrm{~mL}), 70{ }^{\circ} \mathrm{C}$. Conversions were determined by ${ }^{31} \mathrm{P}$ NMR integration following the disappearance of the triphenylphosphine resonance $(\delta \mathrm{P} \sim 19 \mathrm{ppm}$ using a phosphine $\mathrm{Ru}$ complex as internal standard; see experimental section for further details). b) Log-scale of the time-dependent change of the relative concentration for each dihydride complex monitored by ${ }^{31} \mathrm{P}$ NMR spectroscopy. [Ir]o refers to the initial concentration of the dihydride complex and [Ir] to the concentration of this complex at the corresponding reaction time, kobs values as $10^{-6} \mathrm{~s}^{-1}$.

\section{Conclusion}

A new family of pyridyl-carbene iridium(III) complexes bearing hydride ligands has been successfully prepared. The hydride reactivity towards different acids within a large range of $\mathrm{p} K_{\mathrm{a}}$ 
values has been evaluated and showed to be dependent on the acid strength within a limited range ( $\mathrm{p} K_{\mathrm{a}}$ between $\left.0-5\right)$. The hydride reactivity is influenced by the trans effect (carbene $>$ pyridine) rather than the hydridic character determined by NMR chemical shift comparison. While modulation of the electronic properties of the carbene ligand site did not show any correlation with the reactivity of the hydrides, substitution of the pyridyl unit affected the reactivity of the cis hydride, i.e. the hydride located trans to the carbene carbon. Only the hydride trans to the carbene carbon was exchanged selectively, even in the presence of a large excess of acids, which may become an attractive feature for catalytic applications.

\section{Experimental section}

General. Ligands 1-3 and $\operatorname{IrH}_{5}\left(\mathrm{PPh}_{3}\right)_{2}$ were prepared according to literature methods, ${ }^{16,17,29}$ all other reagents and solvents were used as obtained from commercial suppliers. Unless specified, NMR spectra were recorded at $25^{\circ} \mathrm{C}$ on Bruker spectrometers operating at 300 or $400 \mathrm{MHz}\left({ }^{1} \mathrm{H}\right.$ NMR), $100 \mathrm{MHz}\left({ }^{13} \mathrm{C}\right.$ NMR), and $121 \mathrm{MHz}\left({ }^{31} \mathrm{P} \mathrm{NMR}\right)$ respectively. Chemical shifts ( $\delta$ in ppm, coupling constants $J$ in $\mathrm{Hz}$ ) were referenced to residual solvent resonances $\left({ }^{1} \mathrm{H},{ }^{13} \mathrm{C}\right)$. Assignments are based on homo- and heteronuclear shift correlation spectroscopy. All complexes show a quartet around $120 \mathrm{ppm}$ in the ${ }^{13} \mathrm{C}$ NMR spectrum due to the OTf counterion. Purity of the complexes has been established by NMR spectroscopy, and by elemental analysis, which were performed by the University of Bern Microanalytic Laboratory using a Thermo Scientific Flash 2000 CHNS-O elemental analyzer. High-resolution mass spectrometry was carried out with a Thermo Scientific LTQ Orbitrap XL (ESI-TOF).

General procedure for the synthesis of complexes 4-6: A mixture of the pyridyl-triazolium salt (1 eq) and $\operatorname{IrH}_{5}\left(\mathrm{PPh}_{3}\right)_{2}(1 \mathrm{eq})$ in toluene $(15 \mathrm{~mL})$ was refluxed for $24 \mathrm{~h}$. The solvent was removed under reduced pressure and the residue was dissolved in $\mathrm{CH}_{2} \mathrm{Cl}_{2}$ and layered with $\mathrm{Et}_{2} \mathrm{O}$ to induce precipitation of a light yellow solid, which was collected by decantation and dried in vacuo to afford the title complex. The complex was purified via column chromatography $\left(\mathrm{SiO}_{2}\right.$; $\mathrm{CH}_{2} \mathrm{Cl}_{2}$ /acetone, 50:0 to 50:15 gradient).

Complex 4a. A mixture of $1 \mathbf{a}(53 \mathrm{mg}, 0.14 \mathrm{mmol})$ and $\mathrm{IrH}_{5}\left(\mathrm{PPh}_{3}\right)_{2}(100 \mathrm{mg}, 0.14 \mathrm{mmol})$ in toluene $(15 \mathrm{~mL})$ was refluxed for $24 \mathrm{~h}$ according to the general procedure to obtain complex $4 \mathbf{a}$. Yield: $73 \mathrm{mg}(47 \%) .{ }^{1} \mathrm{H}$ NMR (400 MHz, $\left.\mathrm{CD}_{3} \mathrm{CN}\right): \delta=8.29\left(\mathrm{~d},{ }^{3} J_{\mathrm{HH}}=5.4 \mathrm{~Hz}, 1 \mathrm{H}, \mathrm{H}_{\mathrm{py}}\right), 7.89$ $7.81\left(\mathrm{~m}, 1 \mathrm{H}, \mathrm{H}_{\mathrm{py}}\right), 7.72\left(\mathrm{~d},{ }^{3} J_{\mathrm{HH}}=7.8 \mathrm{~Hz}, 1 \mathrm{H}, \mathrm{H}_{\mathrm{py}}\right), 7.50-7.21\left(\mathrm{~m}, 30 \mathrm{H}, \mathrm{H}_{\mathrm{ph}}\right), 6.90\left(\mathrm{ddd},{ }^{3} J_{\mathrm{HH}}=7.8\right.$ $\left.\mathrm{Hz},{ }^{3} J_{\mathrm{HH}}=5.4 \mathrm{~Hz},{ }^{5} J_{\mathrm{HH}}=1.2 \mathrm{~Hz}, 1 \mathrm{H}, \mathrm{H}_{\mathrm{py}}\right), 4.20\left(\mathrm{q},{ }^{3} J_{\mathrm{HH}}=7.2 \mathrm{~Hz}, 2 \mathrm{H}, \mathrm{OCH}_{2} \mathrm{Me}\right), 4.12(\mathrm{~s}, 3 \mathrm{H}$, $\left.\mathrm{NCH}_{3}\right), 1.19\left(\mathrm{t},{ }^{3} J_{\mathrm{HH}}=7.2 \mathrm{~Hz}, 3 \mathrm{H}, \mathrm{OCH}_{2} \mathrm{CH}_{3}\right),-11.08\left(\mathrm{dt},{ }^{2} J_{\mathrm{PH}}=17.0 \mathrm{~Hz},{ }^{2} J_{\mathrm{HH}}=5.9 \mathrm{~Hz}, 1 \mathrm{H}\right.$, $\mathrm{Ir}-\mathrm{H}),-19.85\left(\mathrm{dt},{ }^{2} J_{\mathrm{PH}}=17.0 \mathrm{~Hz},{ }^{2} J_{\mathrm{HH}}=5.9 \mathrm{~Hz}, 1 \mathrm{H}, \mathrm{Ir}-\mathrm{H}\right) .{ }^{13} \mathrm{C}\left\{{ }^{1} \mathrm{H}\right\} \mathrm{NMR}\left(100 \mathrm{MHz}, \mathrm{CD}_{3} \mathrm{CN}\right)$ : 
$\delta=175.0\left(\mathrm{t}, J_{\mathrm{PC}}=5.7 \mathrm{~Hz}, \mathrm{C}_{\mathrm{trz}}-\mathrm{Ir}\right), 158.9(\mathrm{C}=\mathrm{O}), 156.7\left(\mathrm{C}_{\mathrm{py}} \mathrm{H}\right), 150.6\left(\mathrm{C}_{\mathrm{py}}-\mathrm{N}_{\mathrm{trz}}\right), 140.9\left(\mathrm{C}_{\mathrm{py}} \mathrm{H}\right)$, $137.2\left(C_{\mathrm{trz}}-\mathrm{COOEt}\right), 134.3\left(\mathrm{t}, J_{\mathrm{PC}}=27.4 \mathrm{~Hz}, \mathrm{C}_{\mathrm{Ph}}\right), 134.1\left(\mathrm{t}, J_{\mathrm{PC}}=6.2 \mathrm{~Hz}, \mathrm{C}_{\mathrm{Ph}}\right), 131.2\left(\mathrm{C}_{\mathrm{Ph}}\right), 129.1$ $\left(\mathrm{t}, J_{\mathrm{PC}}=5.0 \mathrm{~Hz}, \mathrm{C}_{\mathrm{Ph}}\right), 127.0\left(\mathrm{C}_{\mathrm{py}} \mathrm{H}\right), 115.0\left(\mathrm{C}_{\mathrm{py}} \mathrm{H}\right), 62.9\left(\mathrm{OCH}_{2} \mathrm{Me}\right), 42.2\left(\mathrm{NCH}_{3}\right), 14.3$ $\left(\mathrm{OCH}_{2} \mathrm{CH}_{3}\right) .{ }^{31} \mathrm{P}\left\{{ }^{1} \mathrm{H}\right\}$ NMR $\left(121 \mathrm{MHz}, \mathrm{CD}_{3} \mathrm{CN}\right): \delta=19.5$. Anal. Calcd for $\mathrm{C}_{48} \mathrm{H}_{44} \mathrm{~F}_{3} \mathrm{IrN}_{4} \mathrm{O}_{5} \mathrm{P}_{2} \mathrm{~S}$ (1100.12): C, 52.41; H, 4.03; N, 5.09. Found: C, 52.40; H, 3.60; N, 5.36 HR-MS $\left(\mathrm{CH}_{3} \mathrm{CN}\right): \mathrm{m} / \mathrm{z}$ calculated for $\mathrm{C}_{47} \mathrm{H}_{44} \mathrm{O}_{2} \mathrm{~N}_{4} \mathrm{IrP}_{2}[\mathrm{M}-\mathrm{OTf}]^{+}=951.2563$; found, 951.2552.

Complex 4b. A mixture of $\mathbf{1 b}(57.1 \mathrm{mg}, 0.14 \mathrm{mmol})$ and $\mathrm{IrH}_{5}\left(\mathrm{PPh}_{3}\right)_{2}(100 \mathrm{mg}, 0.14 \mathrm{mmol})$ in toluene $(15 \mathrm{~mL})$ was refluxed for $24 \mathrm{~h}$ according to the general procedure yielding complex $\mathbf{4 b}$. Yield: $61 \mathrm{mg}$ (39\%). ${ }^{1} \mathrm{H}$ NMR (400 MHz, $\mathrm{CD}_{3} \mathrm{CN}$ ): $\delta=7.68-7.60\left(\mathrm{~m}, 2 \mathrm{H}, \mathrm{H}_{\mathrm{py}}\right), 7.53-7.43$ (m, 13H, $\mathrm{H}_{\mathrm{Ph}}+\mathrm{H}_{\mathrm{py}}$ ), 7.39-7.22 (m, 18H, $\left.\mathrm{H}_{\mathrm{Ph}}\right), 4.24$ (q, $\left.{ }^{3} \mathrm{~J}_{\mathrm{HH}}=7.2 \mathrm{~Hz}, 2 \mathrm{H}, \mathrm{OCH}_{2} \mathrm{Me}\right), 4.09$ (s, 3H, $\left.\mathrm{NCH}_{3}\right), 3.60\left(\mathrm{~s}, 3 \mathrm{H}, \mathrm{OCH}_{3}\right), 1.23\left(\mathrm{t},{ }^{3} \mathrm{~J}_{\mathrm{HH}}=7.2 \mathrm{~Hz}, 3 \mathrm{H}, \mathrm{OCH}_{2} \mathrm{CH}_{3}\right),-11.27\left(\mathrm{td},{ }^{2} J_{\mathrm{PH}}=17.0 \mathrm{~Hz}\right.$, $\left.{ }^{2} J_{\mathrm{HH}}=6.0 \mathrm{~Hz}, 1 \mathrm{H}, \mathrm{Ir}-\mathrm{H}\right),-19.95\left(\mathrm{td},{ }^{2} J_{\mathrm{PH}}=17.0 \mathrm{~Hz},{ }^{2} J_{\mathrm{HH}}=6.0 \mathrm{~Hz}, 1 \mathrm{H}, \mathrm{Ir}-\mathrm{H}\right) .{ }^{13} \mathrm{C}\left\{{ }^{1} \mathrm{H}\right\} \mathrm{NMR}(100$ $\left.\mathrm{MHz}, \mathrm{CD}_{3} \mathrm{CN}\right): \delta=173.0\left(\mathrm{t}, J_{\mathrm{PC}}=6.3 \mathrm{~Hz}, \mathrm{C}_{\mathrm{trz}}-\mathrm{Ir}\right), 159.0(\mathrm{C}=\mathrm{O}), 157.9\left(\mathrm{C}_{\mathrm{py}}-\mathrm{OMe}\right), 144.2\left(\mathrm{C}_{\mathrm{py}}-\right.$ $\left.\mathrm{N}_{\text {trz }}\right), 142.2\left(\mathrm{C}_{\mathrm{py}} \mathrm{H}\right), 137.1\left(C_{\mathrm{trz}}-\mathrm{COOEt}\right), 134.3\left(\mathrm{t}, J_{\mathrm{PC}}=27.4 \mathrm{~Hz}, \mathrm{C}_{\mathrm{Ph}}\right), 134.1\left(\mathrm{t}, J_{\mathrm{PC}}=6.2 \mathrm{~Hz}, \mathrm{C}_{\mathrm{Ph}}\right)$, $131.2\left(\mathrm{C}_{\mathrm{Ph}}\right), 129.1\left(\mathrm{t}, J_{\mathrm{PC}}=5.0 \mathrm{~Hz}, \mathrm{C}_{\mathrm{Ph}}\right), 126.3\left(\mathrm{C}_{\mathrm{py}} \mathrm{H}\right), 115.7\left(\mathrm{C}_{\mathrm{py}} \mathrm{H}\right), 62.9\left(\mathrm{OCH}_{2} \mathrm{Me}\right), 57.4$ $\left(\mathrm{OCH}_{3}\right), 42.0\left(\mathrm{NCH}_{3}\right), 14.3\left(\mathrm{OCH}_{2} \mathrm{CH}_{3}\right) .{ }^{31} \mathrm{P}\left\{{ }^{1} \mathrm{H}\right\} \mathrm{NMR}\left(121 \mathrm{MHz}, \mathrm{CD}_{3} \mathrm{CN}\right): \delta=20.0$. Anal. Calcd for $\mathrm{C}_{49} \mathrm{H}_{46} \mathrm{~F}_{3} \mathrm{IrN}_{4} \mathrm{O}_{6} \mathrm{P}_{2} \mathrm{~S}$ (1130.15): C, 52.08; H, 4.10; N, 4.96. Found: C, 52.60; H, 3.72; N, 4.77. HR-MS $\left(\mathrm{CH}_{3} \mathrm{CN}\right): \mathrm{m} / \mathrm{z}$ calculated for $\mathrm{C}_{48} \mathrm{H}_{46} \mathrm{O}_{3} \mathrm{~N}_{4} \mathrm{IrP} \mathrm{P}_{2}[\mathrm{M}-\mathrm{OTf}]^{+}=981.2669$; found, 981.2671.

Complex 4c. A mixture of 1c $(57.1 \mathrm{mg}, 0.14 \mathrm{mmol})$ and $\mathrm{IrH}_{5}\left(\mathrm{PPh}_{3}\right)_{2}(100 \mathrm{mg}, 0.14 \mathrm{mmol})$ in toluene $(15 \mathrm{~mL})$ was refluxed for $24 \mathrm{~h}$ according to the general procedure affording complex $\mathbf{4 c}$. Yield: $47 \mathrm{mg}(30 \%) .{ }^{1} \mathrm{H}$ NMR (400 MHz, $\left.\mathrm{CD}_{3} \mathrm{CN}\right): \delta=8.02\left(\mathrm{~d},{ }^{3} J_{\mathrm{HH}}=6.6 \mathrm{~Hz}, 1 \mathrm{H}, \mathrm{H}_{\mathrm{py}}\right), 7.54$ $7.43\left(\mathrm{~m}, 12 \mathrm{H}, \mathrm{H}_{\mathrm{Ph}}\right), 7.40-7.30\left(\mathrm{~m}, 18 \mathrm{H}, \mathrm{H}_{\mathrm{Ph}}\right), 7.18\left(\mathrm{~d},{ }^{4} J_{\mathrm{HH}}=2.6 \mathrm{~Hz}, 1 \mathrm{H}, \mathrm{H}_{\mathrm{py}}\right), 6.45\left(\mathrm{dd},{ }^{3} J_{\mathrm{HH}}=\right.$ $\left.6.6 \mathrm{~Hz},{ }^{4} J_{\mathrm{HH}}=2.6 \mathrm{~Hz}, 1 \mathrm{H}, \mathrm{H}_{\mathrm{py}}\right), 4.20\left(\mathrm{q},{ }^{3} \mathrm{~J}_{\mathrm{HH}}=7.2 \mathrm{~Hz}, 2 \mathrm{H}, \mathrm{OCH}_{2} \mathrm{Me}\right), 4.09\left(\mathrm{~s}, 3 \mathrm{H}, \mathrm{NCH}_{3}\right), 3.86$ $\left(\mathrm{s}, 3 \mathrm{H}, \mathrm{OCH}_{3}\right), 1.19\left(\mathrm{t},{ }^{3} J_{\mathrm{HH}}=7.2 \mathrm{~Hz}, 3 \mathrm{H}, \mathrm{OCH}_{2} \mathrm{CH}_{3}\right),-11.14\left(\mathrm{td},{ }^{2} J_{\mathrm{PH}}=17.0 \mathrm{~Hz},{ }^{2} J_{\mathrm{HH}}=6.0 \mathrm{~Hz}\right.$, $1 \mathrm{H}, \mathrm{Ir}-\mathrm{H}),-20.10\left(\mathrm{td},{ }^{2} J_{\mathrm{PH}}=17.0 \mathrm{~Hz},{ }^{2} J_{\mathrm{HH}}=6.0 \mathrm{~Hz}, 1 \mathrm{H}, \mathrm{Ir}-\mathrm{H}\right) .{ }^{13} \mathrm{C}\left\{{ }^{1} \mathrm{H}\right\} \mathrm{NMR}(100 \mathrm{MHz}$, $\left.\mathrm{CD}_{3} \mathrm{CN}\right): \delta=175.6\left(\mathrm{t}, J_{\mathrm{PC}}=5.4 \mathrm{~Hz}, \mathrm{C}_{\mathrm{trz}}-\mathrm{Ir}\right), 169.1\left(\mathrm{C}_{\mathrm{py}}-\mathrm{OMe}\right), 158.9(\mathrm{C}=\mathrm{O}), 157.0\left(\mathrm{C}_{\mathrm{py}} \mathrm{H}\right), 152.1$ $\left(\mathrm{C}_{\mathrm{py}}-\mathrm{N}_{\mathrm{trz}}\right), 137.2\left(C_{\mathrm{trz}}-\mathrm{COOEt}\right), 134.5\left(\mathrm{t}, J_{\mathrm{PC}}=27.2 \mathrm{~Hz}, \mathrm{C}_{\mathrm{Ph}}\right), 134.1\left(\mathrm{t}, J_{\mathrm{PC}}=6.2 \mathrm{~Hz}, \mathrm{C}_{\mathrm{Ph}}\right), 131.1$ $\left(\mathrm{C}_{\mathrm{Ph}}\right), 129.1\left(\mathrm{t}, J_{\mathrm{PC}}=5.0 \mathrm{~Hz}, \mathrm{C}_{\mathrm{Ph}}\right), 113.7\left(\mathrm{C}_{\mathrm{py}} \mathrm{H}\right), 101.0\left(\mathrm{C}_{\mathrm{py}} \mathrm{H}\right), 62.9\left(\mathrm{OCH}_{2} \mathrm{Me}\right), 57.7\left(\mathrm{OCH}_{3}\right)$, $42.2\left(\mathrm{NCH}_{3}\right), 14.3\left(\mathrm{OCH}_{2} \mathrm{CH}_{3}\right) .{ }^{31} \mathrm{P}\left\{{ }^{1} \mathrm{H}\right\} \mathrm{NMR}\left(121 \mathrm{MHz}, \mathrm{CD}_{3} \mathrm{CN}\right): \delta=19.7$. Anal. Calcd for $\mathrm{C}_{49} \mathrm{H}_{46} \mathrm{~F}_{3} \mathrm{IrN}_{4} \mathrm{O}_{6} \mathrm{P}_{2} \mathrm{~S}$ (1130.15): C, 52.08; H, 4.10; N, 4.96. Found: C, 51.59; H, 3.85; N, 4.71. HRMS $\left(\mathrm{CH}_{3} \mathrm{CN}\right): \mathrm{m} / \mathrm{z}$ calculated for $\mathrm{C}_{48} \mathrm{H}_{46} \mathrm{O}_{3} \mathrm{~N}_{4} \mathrm{IrP}_{2}[\mathrm{M}-\mathrm{OTf}]^{+}=981.2669$; found, 981.2676.

Complex 5. A mixture of 2 (48 mg, $0.13 \mathrm{mmol})$ and $\mathrm{IrH}_{5}\left(\mathrm{PPh}_{3}\right)_{2}(98.3 \mathrm{mg}, 0.13 \mathrm{mmol})$ in toluene $(15 \mathrm{~mL})$ was refluxed for $24 \mathrm{~h}$ according to the general procedure affording complex $\mathbf{5}$. Yield: 50 
$\operatorname{mg}(36 \%) .{ }^{1} \mathrm{H}$ NMR $\left(400 \mathrm{MHz}, \mathrm{CD}_{3} \mathrm{CN}\right): \delta=8.36\left(\mathrm{~d},{ }^{3} J_{\mathrm{HH}}=5.5 \mathrm{~Hz}, 1 \mathrm{H}, \mathrm{H}_{\mathrm{py}}\right), 7.73\left(\mathrm{t},{ }^{3} J_{\mathrm{HH}}=8.0\right.$ $\left.\mathrm{Hz}, 1 \mathrm{H}, \mathrm{H}_{\mathrm{py}}\right), 7.47\left(\mathrm{~d},{ }^{3} \mathrm{JHH}_{\mathrm{HH}}=8.0 \mathrm{~Hz}, 1 \mathrm{H}, \mathrm{H}_{\mathrm{py}}\right), 7.43-7.22\left(\mathrm{~m}, 30 \mathrm{H}, \mathrm{H}_{\mathrm{Ph}}\right), 6.92-6.84\left(\mathrm{~m}, 1 \mathrm{H}, \mathrm{H}_{\mathrm{py}}\right)$, $3.90\left(\mathrm{~s}, 3 \mathrm{H}, \mathrm{NCH}_{3}\right), 2.08-2.01\left(\mathrm{~m}, 2 \mathrm{H}, \mathrm{CH}_{2}\right), 0.80-0.70\left(\mathrm{~m}, 2 \mathrm{H}, \mathrm{CH}_{2}\right), 0.66\left(\mathrm{t},{ }^{3} \mathrm{~J}_{\mathrm{HH}}=7.0 \mathrm{~Hz}, 3 \mathrm{H}\right.$, $\left.\mathrm{CH}_{3}\right),-10.95\left(\mathrm{td},{ }^{2} J_{\mathrm{PH}}=17.0 \mathrm{~Hz},{ }^{2} J_{\mathrm{HH}}=6 \mathrm{~Hz}, 1 \mathrm{H}, \mathrm{Ir}-\mathrm{H}\right),-20.04\left(\mathrm{td},{ }^{2} J_{\mathrm{PH}}=17.0 \mathrm{~Hz},{ }^{2} J_{\mathrm{HH}}=6 \mathrm{~Hz}\right.$, $1 \mathrm{H}, \mathrm{Ir}-\mathrm{H}) .{ }^{13} \mathrm{C}\left\{{ }^{1} \mathrm{H}\right\} \mathrm{NMR}\left(100 \mathrm{MHz}, \mathrm{CD}_{3} \mathrm{CN}\right): \delta=165.0$ (t, $\left.J_{\mathrm{PC}}=6.9 \mathrm{~Hz}, \mathrm{C}_{\mathrm{trz}}-\mathrm{Ir}\right), 156.5\left(\mathrm{C}_{\mathrm{py}} \mathrm{H}\right)$, $151.5\left(\mathrm{C}_{\mathrm{py}}-\mathrm{N}_{\mathrm{trz}}\right), 148.2\left(C_{\mathrm{trz}}-\mathrm{CH}_{2} \mathrm{CH}_{2} \mathrm{CH}_{3}\right), 140.4\left(\mathrm{C}_{\mathrm{py}} \mathrm{H}\right), 134.2\left(\mathrm{t}, J_{\mathrm{PC}}=26.9 \mathrm{~Hz}, \mathrm{C}_{\mathrm{Ph}}\right), 134.0(\mathrm{t}$, $\left.J_{\mathrm{PC}}=6.1 \mathrm{~Hz}, \mathrm{C}_{\mathrm{Ph}}\right), 131.1\left(\mathrm{C}_{\mathrm{Ph}}\right), 129.2\left(\mathrm{t}, J_{\mathrm{PC}}=5.0 \mathrm{~Hz}, \mathrm{C}_{\mathrm{Ph}}\right), 126.4\left(\mathrm{C}_{\mathrm{py}} \mathrm{H}\right), 114.8\left(\mathrm{C}_{\mathrm{py}} \mathrm{H}\right), 38.0$ $\left(\mathrm{NCH}_{3}\right), 27.7\left(\mathrm{CH}_{2}\right), 21.8\left(\mathrm{CH}_{2}\right), 14.6\left(\mathrm{CH}_{3}\right) .{ }^{31} \mathrm{P}\left\{{ }^{1} \mathrm{H}\right\} \mathrm{NMR}\left(121 \mathrm{MHz}, \mathrm{CD}_{3} \mathrm{CN}\right): \delta=19.7$. Anal. Calcd for $\mathrm{C}_{50} \mathrm{H}_{49} \mathrm{~F}_{3} \mathrm{IrN}_{5} \mathrm{O}_{3} \mathrm{P}_{2} \mathrm{~S}+\mathrm{CH}_{3} \mathrm{CN}$ (1111.19): C, 54.05; H, 4.44; N, 6.30. Found: C, 54.52; $\mathrm{H}, 4.59 ; \mathrm{N}, 6.66$. HR-MS $\left(\mathrm{CH}_{3} \mathrm{CN}\right): \mathrm{m} / \mathrm{z}$ calculated for $\mathrm{C}_{47} \mathrm{H}_{46} \mathrm{~N}_{4} \mathrm{IrP}_{2}[\mathrm{M}-\mathrm{OTf}]^{+}=921.2827$; found, 921.2837 .

Complex 6. A mixture of $\mathbf{3}(49 \mathrm{mg}, 0.14 \mathrm{mmol})$ and $\mathrm{IrH}_{5}\left(\mathrm{PPh}_{3}\right)_{2}(100 \mathrm{mg}, 0.14 \mathrm{mmol})$ in toluene $(15 \mathrm{~mL})$ was refluxed for $24 \mathrm{~h}$ according to the general procedure affording complex 6 . Yield: 62 mg (41\%). ${ }^{1} \mathrm{H}$ NMR (400 MHz, $\left.\mathrm{CD}_{3} \mathrm{CN}\right): \delta=8.30\left(\mathrm{~d},{ }^{3} J_{\mathrm{HH}}=5.5 \mathrm{~Hz}, 1 \mathrm{H}, \mathrm{H}_{\mathrm{py}}\right), 7.78-7.67(\mathrm{~m}, 1 \mathrm{H}$, $\left.\mathrm{H}_{\mathrm{py}}\right), 7.51\left(\mathrm{~d},{ }^{3} \mathrm{~J}_{\mathrm{HH}}=8.3 \mathrm{~Hz}, 1 \mathrm{H}, \mathrm{H}_{\mathrm{py}}\right), 7.45-7.16\left(\mathrm{~m}, 30 \mathrm{H}, \mathrm{H}_{\mathrm{Ph}}\right), 6.93-6.81\left(\mathrm{~m}, 1 \mathrm{H}, \mathrm{H}_{\mathrm{py}}\right), 3.87$ (q, $\left.{ }^{3} J_{\mathrm{HH}}=7.2 \mathrm{~Hz}, 2 \mathrm{H}, \mathrm{OCH}_{2} \mathrm{Me}\right), 3.70\left(\mathrm{~s}, 3 \mathrm{H}, \mathrm{NCH}_{3}\right), 0.95\left(\mathrm{t},{ }^{3} \mathrm{~J}_{\mathrm{HH}}=7.2 \mathrm{~Hz}, 3 \mathrm{H}, \mathrm{OCH}_{2} \mathrm{CH}_{3}\right),-11.52$ $\left(\mathrm{td},{ }^{2} J_{\mathrm{PH}}=17.0 \mathrm{~Hz},{ }^{2} J_{\mathrm{HH}}=6.1 \mathrm{~Hz}, 1 \mathrm{H}, \mathrm{Ir}-\mathrm{H}\right),-20.16\left(\mathrm{td},{ }^{2} J_{\mathrm{PH}}=17.0 \mathrm{~Hz},{ }^{2} J_{\mathrm{HH}}=6.1 \mathrm{~Hz}, 1 \mathrm{H}, \mathrm{Ir}-\mathrm{H}\right)$. ${ }^{13} \mathrm{C}\left\{{ }^{1} \mathrm{H}\right\}$ NMR $\left(100 \mathrm{MHz}, \mathrm{CD}_{3} \mathrm{CN}\right): \delta=157.6\left(\mathrm{C}_{\mathrm{trz}}-\mathrm{OEt}\right), 156.4\left(\mathrm{C}_{\mathrm{py}} \mathrm{H}\right), 151.3\left(\mathrm{C}_{\mathrm{py}}-\mathrm{N}_{\mathrm{trz}}\right), 146.0$ $\left(\mathrm{t}, J_{\mathrm{PC}}=6.3 \mathrm{~Hz}, \mathrm{C}_{\mathrm{trz}}-\mathrm{Ir}\right), 140.4\left(\mathrm{C}_{\mathrm{py}} \mathrm{H}\right), 134.1\left(\mathrm{t}, J_{\mathrm{PC}}=26.09 \mathrm{~Hz}, \mathrm{C}_{\mathrm{Ph}}\right), 134.0\left(\mathrm{t}, J_{\mathrm{PC}}=6.2 \mathrm{~Hz}, \mathrm{C}_{\mathrm{Ph}}\right)$, $131.1\left(\mathrm{C}_{\mathrm{Ph}}\right), 129.2\left(\mathrm{t}, J_{\mathrm{PC}}=5.0 \mathrm{~Hz}, \mathrm{C}_{\mathrm{Ph}}\right), 126.6\left(\mathrm{C}_{\mathrm{py}} \mathrm{H}\right), 114.6\left(\mathrm{C}_{\mathrm{py}} \mathrm{H}\right), 70.4\left(\mathrm{OCH}_{2} \mathrm{Me}\right), 35.0$ $\left(\mathrm{NCH}_{3}\right), 15.2\left(\mathrm{OCH}_{2} \mathrm{CH}_{3}\right) .{ }^{31} \mathrm{P}\left\{{ }^{1} \mathrm{H}\right\} \mathrm{NMR}\left(121 \mathrm{MHz}, \mathrm{CD}_{3} \mathrm{CN}\right): \delta=18.89$. Anal. Calcd for $\mathrm{C}_{47} \mathrm{H}_{44} \mathrm{~F}_{3} \mathrm{IrN}_{4} \mathrm{O}_{4} \mathrm{P}_{2} \mathrm{~S}$ (1072.11): C, 52.65; H, 4.14; N, 5.23. Found: C, 52.40; H, 3.78; N, 5.07. HR-MS $\left(\mathrm{CH}_{3} \mathrm{CN}\right): \mathrm{m} / \mathrm{z}$ calculated for $\mathrm{C}_{46} \mathrm{H}_{44} \mathrm{ON}_{4} \mathrm{IrP}_{2}[\mathrm{M}-\mathrm{OTf}]^{+}=923.2614$; found, 923.2625.

General procedure for the reaction of complex $4 \mathrm{a}$ with acids. In a NMR tube, complex $4 \mathbf{a}(1$ eq) and an excess of the corresponding acid (200 eq) in $\mathrm{CDCl}_{3}$ or $\mathrm{CD}_{3} \mathrm{CN}(0.4 \mathrm{~mL})$ was followed by ${ }^{1} \mathrm{H}$ and ${ }^{31} \mathrm{P}$ NMR spectroscopy until the reaction was finished. The reaction was carried out at room temperature or elevated temperature $\left(70{ }^{\circ} \mathrm{C}\right)$. The residue was layered with $\mathrm{Et}_{2} \mathrm{O}$ to induce precipitation of a white solid, which was dried under reduced pressure to afford the title complex.

Complex 7. From 4a (5 mg, $0.004 \mathrm{mmol})$ and phosphoric acid (60 $\mu \mathrm{L}, 0.87 \mathrm{mmol})$ in $\mathrm{CDCl}_{3}(0.4$ $\mathrm{mL})$ after $38 \mathrm{~h}$ at $70{ }^{\circ} \mathrm{C} .{ }^{1} \mathrm{H} \mathrm{NMR}\left(400 \mathrm{MHz}, \mathrm{CD}_{3} \mathrm{CN}\right): \delta=9.12\left(\mathrm{~d},{ }^{3} \mathrm{JHH}_{\mathrm{HH}}=5.4 \mathrm{~Hz}, 1 \mathrm{H}, \mathrm{H}_{\mathrm{py}}\right), 8.10$ $\left(\mathrm{t},{ }^{3} J_{\mathrm{HH}}=8.4 \mathrm{~Hz}, 1 \mathrm{H}, \mathrm{H}_{\mathrm{py}}\right), 8.06\left(\mathrm{~d},{ }^{3} J_{\mathrm{HH}}=8.4 \mathrm{~Hz}, 1 \mathrm{H}, \mathrm{H}_{\mathrm{py}}\right), 7.56-7.50\left(\mathrm{~m}, 1 \mathrm{H}, \mathrm{H}_{\mathrm{py}}\right), 7.47-7.24$ (m, 30H, $\left.\mathrm{H}_{\mathrm{Ph}}\right), 4.01-3.88\left(\mathrm{~m}, 2 \mathrm{H}, \mathrm{OCH}_{2} \mathrm{Me}\right), 3.98\left(\mathrm{~s}, 3 \mathrm{H}, \mathrm{NCH}_{3}\right), 1.31\left(\mathrm{t},{ }^{3} J_{\mathrm{HH}}=7.2 \mathrm{~Hz}, 3 \mathrm{H}\right.$, $\left.\mathrm{OCH}_{2} \mathrm{CH}_{3}\right),-17.25\left(\mathrm{t},{ }^{2} J_{\mathrm{PH}}=14.1 \mathrm{~Hz}, 1 \mathrm{H}, \mathrm{Ir}-\mathrm{H}\right) .{ }^{13} \mathrm{C}\left\{{ }^{1} \mathrm{H}\right\} \mathrm{NMR}\left(100 \mathrm{MHz}, \mathrm{CD}_{3} \mathrm{CN}\right): \delta=156.8$ $(\mathrm{C}=\mathrm{O}), 152.7\left(\mathrm{t}, \mathrm{C}_{\mathrm{trz}}-\mathrm{Ir}\right), 151.7\left(\mathrm{C}_{\mathrm{py}} \mathrm{H}\right), 149.4\left(\mathrm{C}_{\mathrm{py}}-\mathrm{N}_{\mathrm{trz}}\right), 142.6\left(\mathrm{C}_{\mathrm{py}} \mathrm{H}\right), 134.8\left(C_{\mathrm{trz}}-\mathrm{COOEt}\right), 134.5$ 
$\left(\mathrm{t}, J_{\mathrm{PC}}=5.6 \mathrm{~Hz}, \mathrm{C}_{\mathrm{Ph}}\right), 131.9\left(\mathrm{C}_{\mathrm{Ph}}\right), 131.4\left(\mathrm{t}, J_{\mathrm{PC}}=27.7 \mathrm{~Hz}, \mathrm{C}_{\mathrm{Ph}}\right), 129.2\left(\mathrm{t}, J_{\mathrm{PC}}=5.0 \mathrm{~Hz}, \mathrm{C}_{\mathrm{Ph}}\right), 127.5$ $\left(\mathrm{C}_{\mathrm{py}} \mathrm{H}\right), 115.1\left(\mathrm{C}_{\mathrm{py}} \mathrm{H}\right), 63.1\left(\mathrm{OCH}_{2} \mathrm{Me}\right), 43.3\left(\mathrm{NCH}_{3}\right), 14.4\left(\mathrm{OCH}_{2} \mathrm{CH}_{3}\right) .{ }^{31} \mathrm{P}\left\{{ }^{1} \mathrm{H}\right\} \mathrm{NMR}(121 \mathrm{MHz}$, $\left.\mathrm{CD}_{3} \mathrm{CN}\right): \delta=0$. HR-MS $\left(\mathrm{CH}_{3} \mathrm{CN}\right): \mathrm{m} / \mathrm{z}$ calculated for $\mathrm{C}_{47} \mathrm{H}_{43} \mathrm{ClIrN}_{4} \mathrm{O}_{2} \mathrm{P}_{2}[\mathrm{M}-\mathrm{OTf}]^{+}=985.2179$; found, 985.2155 .

Complex 8. From 4a (5 mg, $0.004 \mathrm{mmol})$ and dichloroacetic acid $(72 \mu \mathrm{L}, 0.87 \mathrm{mmol})$ in $\mathrm{CDCl}_{3}$ $(0.4 \mathrm{~mL})$ after $20 \mathrm{~h}$ at $70{ }^{\circ} \mathrm{C} .{ }^{1} \mathrm{H}$ NMR $\left(400 \mathrm{MHz}, \mathrm{CD}_{3} \mathrm{CN}\right): \delta=9.26\left(\mathrm{~d},{ }^{3} J_{\mathrm{HH}}=5.5 \mathrm{~Hz}, 1 \mathrm{H}, \mathrm{H}_{\mathrm{py}}\right)$, $8.05\left(\mathrm{t},{ }^{3} J_{\mathrm{HH}}=8.0 \mathrm{~Hz}, 1 \mathrm{H}, \mathrm{H}_{\mathrm{py}}\right), 7.73-7.68\left(\mathrm{~m}, 1 \mathrm{H}, \mathrm{H}_{\mathrm{py}}\right), 7.62\left(\mathrm{~d},{ }^{3} J_{\mathrm{HH}}=8.0 \mathrm{~Hz}, 1 \mathrm{H}, \mathrm{H}_{\mathrm{py}}\right), 7.49-$ $7.28\left(\mathrm{~m}, 30 \mathrm{H}, \mathrm{H}_{\mathrm{Ph}}\right), 5.5\left(\mathrm{~s}, 1 \mathrm{H}, \mathrm{CHCl}_{2}\right), 4.1\left(\mathrm{~s}, 3 \mathrm{H}, \mathrm{NCH}_{3}\right), 4.03\left(\mathrm{q},{ }^{3} J_{\mathrm{HH}}=7.2 \mathrm{~Hz}, 2 \mathrm{H}, \mathrm{OCH}_{2} \mathrm{Me}\right)$, $1.26\left(\mathrm{t},{ }^{3} J_{\mathrm{HH}}=7.2 \mathrm{~Hz}, 3 \mathrm{H}, \mathrm{OCH}_{2} \mathrm{CH}_{3}\right),-16.64\left(\mathrm{t},{ }^{2} J_{\mathrm{PH}}=13.3 \mathrm{~Hz}, 1 \mathrm{H}, \mathrm{Ir}-\mathrm{H}\right) .{ }^{13} \mathrm{C}\left\{{ }^{1} \mathrm{H}\right\} \mathrm{NMR}(100$ $\left.\mathrm{MHz}, \mathrm{CD}_{3} \mathrm{CN}\right): \delta=168.1\left(\mathrm{Cl}_{2} \mathrm{CHC}=\mathrm{O}\right), \delta=157.4(\mathrm{C}=\mathrm{O}), 151.3\left(\mathrm{C}_{\mathrm{py}} \mathrm{H}\right), 148.8\left(\mathrm{C}_{\mathrm{py}}-\mathrm{N}_{\mathrm{trz}}\right), 147.9$ $\left(\mathrm{C}_{\mathrm{trz}}-\mathrm{Ir}\right), 142.7\left(\mathrm{C}_{\mathrm{py}} \mathrm{H}\right), 136.2\left(C_{\mathrm{trz}}-\mathrm{COOEt}\right), 134.3\left(\mathrm{t}, J_{\mathrm{PC}}=5.8 \mathrm{~Hz}, \mathrm{C}_{\mathrm{Ph}}\right), 131.9\left(\mathrm{C}_{\mathrm{Ph}}\right), 129.8\left(\mathrm{t}, J_{\mathrm{PC}}\right.$ $\left.=27.6 \mathrm{~Hz}, \mathrm{C}_{\mathrm{Ph}}\right), 129.4\left(\mathrm{t}, J_{\mathrm{PC}}=5.1 \mathrm{~Hz}, \mathrm{C}_{\mathrm{Ph}}\right), 127.6\left(\mathrm{C}_{\mathrm{py}} \mathrm{H}\right), 115.3\left(\mathrm{C}_{\mathrm{py}} \mathrm{H}\right), 67.5\left(\mathrm{Cl}_{2} \mathrm{CH}\right), 63.4$ $\left(\mathrm{OCH}_{2} \mathrm{Me}\right), 42.9\left(\mathrm{NCH}_{3}\right), 14.6\left(\mathrm{OCH}_{2} \mathrm{CH}_{3}\right) .{ }^{31} \mathrm{P}\left\{{ }^{1} \mathrm{H}\right\} \mathrm{NMR}\left(121 \mathrm{MHz}, \mathrm{CD}_{3} \mathrm{CN}\right): \delta=5.6 . \mathrm{HR}-\mathrm{MS}$ $\left(\mathrm{CH}_{3} \mathrm{CN}\right): \mathrm{m} / \mathrm{z}$ calculated for $\mathrm{C}_{49} \mathrm{H}_{44} \mathrm{Cl}_{2} \mathrm{IrN}_{4} \mathrm{O}_{4} \mathrm{P}_{2}[\mathrm{M}-\mathrm{OTf}]^{+}=1077.1844$; found, 1077.1839 .

Complex 9. From 4a (5 mg, $0.004 \mathrm{mmol})$ and trifluoroacetic acid ( $67 \mu \mathrm{L}, 0.87 \mathrm{mmol})$ in $\mathrm{CDCl}_{3}$ $(0.4 \mathrm{~mL})$ after $5 \mathrm{~min}$ at room temperature. ${ }^{1} \mathrm{H} \mathrm{NMR}\left(400 \mathrm{MHz}, \mathrm{CD}_{3} \mathrm{CN}\right): \delta=9.18\left(\mathrm{~d},{ }^{3} \mathrm{JHH}_{\mathrm{HH}}=5.5\right.$ $\left.\mathrm{Hz}, 1 \mathrm{H}, \mathrm{H}_{\mathrm{py}}\right), 8.10-7.96\left(\mathrm{~m}, 1 \mathrm{H}, \mathrm{H}_{\mathrm{py}}\right), 7.75-7.66\left(\mathrm{~m}, 1 \mathrm{H}, \mathrm{H}_{\mathrm{py}}\right), 7.60\left(\mathrm{~d},{ }^{3} J_{\mathrm{HH}}=8.2 \mathrm{~Hz}, 1 \mathrm{H}, \mathrm{H}_{\mathrm{py}}\right)$, 7.47-7.25 (m, 30H, $\left.\mathrm{H}_{\mathrm{Ph}}\right), 4.11\left(\mathrm{~s}, 3 \mathrm{H}, \mathrm{NCH}_{3}\right), 4.06$ (q, $\left.{ }^{3} J_{\mathrm{HH}}=7.1 \mathrm{~Hz}, 2 \mathrm{H}, \mathrm{OCH}_{2} \mathrm{Me}\right), 1.27\left(\mathrm{t},{ }^{3} J_{\mathrm{HH}}\right.$ $\left.=7.1 \mathrm{~Hz}, 3 \mathrm{H}, \mathrm{OCH}_{2} \mathrm{CH}_{3}\right),-16.61\left(\mathrm{t},{ }^{2} \mathrm{~J}_{\mathrm{PH}}=13.2 \mathrm{~Hz}, 1 \mathrm{H}, \mathrm{Ir}-\mathrm{H}\right) .{ }^{13} \mathrm{C}\left\{{ }^{1} \mathrm{H}\right\} \mathrm{NMR}\left(100 \mathrm{MHz}, \mathrm{CDCl}_{3}\right)$ : $\delta=207.1\left(\mathrm{CF}_{3} C=\mathrm{O}\right), 156.6(\mathrm{C}=\mathrm{O}), 148.9\left(\mathrm{C}_{\mathrm{py}}-\mathrm{N}_{\mathrm{trz}}\right), 148.1\left(\mathrm{C}_{\mathrm{py}} \mathrm{H}\right), 146.6\left(\mathrm{C}_{\mathrm{trz}}-\mathrm{Ir}\right), 142.6\left(\mathrm{C}_{\mathrm{py}} \mathrm{H}\right)$, $134.9\left(C_{\mathrm{trz}}-\mathrm{COOEt}\right), 133.3\left(\mathrm{t}, J_{\mathrm{PC}}=5.7 \mathrm{~Hz}, \mathrm{C}_{\mathrm{Ph}}\right), 131.3\left(\mathrm{C}_{\mathrm{Ph}}\right), 128.6\left(\mathrm{t}, J_{\mathrm{PC}}=5.1 \mathrm{~Hz}, \mathrm{C}_{\mathrm{Ph}}\right), 128.3$ $\left(\mathrm{t}, J_{\mathrm{PC}}=27.7 \mathrm{~Hz}, \mathrm{C}_{\mathrm{Ph}}\right), 126.1\left(\mathrm{C}_{\mathrm{py}} \mathrm{H}\right), 116.0\left(\mathrm{CF}_{3}\right), 62.5\left(\mathrm{OCH}_{2} \mathrm{Me}\right), 42.6\left(\mathrm{NCH}_{3}\right), 14.2$ $\left(\mathrm{OCH}_{2} \mathrm{CH}_{3}\right)$, one $\mathrm{C}_{\mathrm{py}}$ not resolved. ${ }^{31} \mathrm{P}\left\{{ }^{1} \mathrm{H}\right\} \mathrm{NMR}\left(121 \mathrm{MHz}, \mathrm{CD}_{3} \mathrm{CN}\right): \delta=6.4$. HR-MS $\left(\mathrm{CH}_{3} \mathrm{CN}\right)$ : $\mathrm{m} / \mathrm{z}$ calculated for $\mathrm{C}_{49} \mathrm{H}_{43} \mathrm{~F}_{3} \mathrm{IrN}_{4} \mathrm{O}_{4} \mathrm{P}_{2}[\mathrm{M}-\mathrm{OTf}]^{+}=1063.2341$; found, 1063.2338 .

Complex 10. From 4a (5 mg, $0.004 \mathrm{mmol})$ and nitric acid $(62 \mu \mathrm{L}, 0.87 \mathrm{mmol})$ in $\mathrm{CDCl}_{3}(0.4 \mathrm{~mL})$ after $15 \mathrm{~min}$ at $70{ }^{\circ} \mathrm{C} .{ }^{1} \mathrm{H}$ NMR $\left(300 \mathrm{MHz}, \mathrm{CD}_{3} \mathrm{CN}\right): \delta=9.07\left(\mathrm{~d},{ }^{3} J_{\mathrm{HH}}=5.5 \mathrm{~Hz}, 1 \mathrm{H}, \mathrm{H}_{\mathrm{py}}\right), 8.04(\mathrm{td}$, $\left.{ }^{3} J_{\mathrm{HH}}=8.0 \mathrm{~Hz},{ }^{3} J_{\mathrm{HH}}=1.6 \mathrm{~Hz} 1 \mathrm{H}, \mathrm{H}_{\mathrm{py}}\right), 7.68-7.58\left(\mathrm{~m}, 2 \mathrm{H}, \mathrm{H}_{\mathrm{py}}\right), 7.50-7.27\left(\mathrm{~m}, 30 \mathrm{H}, \mathrm{H}_{\mathrm{Ph}}\right), 4.12(\mathrm{q}$, $\left.{ }^{3} J_{\mathrm{HH}}=7.2 \mathrm{~Hz}, 2 \mathrm{H}, \mathrm{OCH}_{2} \mathrm{Me}\right), 4.10\left(\mathrm{~s}, 3 \mathrm{H}, \mathrm{NCH}_{3}\right), 1.30\left(\mathrm{t},{ }^{3} \mathrm{~J}_{\mathrm{HH}}=7.2 \mathrm{~Hz}, 3 \mathrm{H}, \mathrm{OCH}_{2} \mathrm{CH}_{3}\right),-16.38$ $\left(\mathrm{t},{ }^{2} J_{\mathrm{PH}}=12.8 \mathrm{~Hz}, 1 \mathrm{H}, \mathrm{Ir}-\mathrm{H}\right) .{ }^{31} \mathrm{P}\left\{{ }^{1} \mathrm{H}\right\} \mathrm{NMR}\left(121 \mathrm{MHz}, \mathrm{CD}_{3} \mathrm{CN}\right): \delta=7.4$. HR-MS $\left(\mathrm{CH}_{3} \mathrm{CN}\right): \mathrm{m} / \mathrm{z}$ calculated for $\mathrm{C}_{47} \mathrm{H}_{43} \mathrm{IrN}_{5} \mathrm{O}_{5} \mathrm{P}_{2}[\mathrm{M}-\mathrm{OTf}]^{+}=1012.2374$; found, 1012.2361 .

Complex 11. From 4a (5 mg, $0.004 \mathrm{mmol})$, with $\mathrm{H}_{2} \mathrm{O}_{2}(10 \mu \mathrm{L}, 0.28 \mathrm{mmol})$ and $\mathrm{CuI}(2 \mathrm{mg}, 0.010$ $\mathrm{mmol})$ in $\mathrm{CDCl}_{3}(0.4 \mathrm{~mL})$ after $5 \mathrm{~min}$ at room temperature. ${ }^{1} \mathrm{H} \mathrm{NMR}\left(400 \mathrm{MHz}, \mathrm{CD}_{3} \mathrm{CN}\right): \delta=$ 
$9.37\left(\mathrm{~d},{ }^{3} J_{\mathrm{HH}}=5.4 \mathrm{~Hz}, 1 \mathrm{H}, \mathrm{H}_{\mathrm{py}}\right), 8.19\left(\mathrm{t},{ }^{3} J_{\mathrm{HH}}=8.0 \mathrm{~Hz}, 1 \mathrm{H}, \mathrm{H}_{\mathrm{py}}\right), 8.11\left(\mathrm{~d},{ }^{3} J_{\mathrm{HH}}=8.0 \mathrm{~Hz}, 1 \mathrm{H}, \mathrm{H}_{\mathrm{py}}\right)$, 7.64-7.59 (m, 1H, $\left.\mathrm{H}_{\mathrm{py}}\right), 7.46-7.26\left(\mathrm{~m}, 30 \mathrm{H}, \mathrm{H}_{\mathrm{Ph}}\right), 4.09$ (q, $\left.{ }^{3} J_{\mathrm{HH}}=7.2 \mathrm{~Hz}, 2 \mathrm{H}, \mathrm{OCH}_{2} \mathrm{Me}\right), 3.97$ (s, $\left.3 \mathrm{H}, \mathrm{NCH}_{3}\right), 1.40\left(\mathrm{t},{ }^{3} \mathrm{~J}_{\mathrm{HH}}=7.2 \mathrm{~Hz}, 3 \mathrm{H}, \mathrm{OCH}_{2} \mathrm{CH}_{3}\right),-17.93\left(\mathrm{t},{ }^{2} \mathrm{~J}_{\mathrm{PH}}=13.9 \mathrm{~Hz}, 1 \mathrm{H}, \mathrm{Ir}-\mathrm{H}\right) .{ }^{13} \mathrm{C}\left\{{ }^{1} \mathrm{H}\right\}$ NMR (100 MHz, CD $\left.{ }_{3} \mathrm{CN}\right): \delta=156.9(\mathrm{C}=\mathrm{O}), 154.5\left(\mathrm{C}_{\mathrm{py}} \mathrm{H}\right), 154.3\left(\mathrm{t}, \mathrm{C}_{\mathrm{trz}}-\mathrm{Ir}\right), 149.5\left(\mathrm{C}_{\mathrm{py}}-\mathrm{N}_{\mathrm{trz}}\right)$, $142.9\left(\mathrm{C}_{\mathrm{py}} \mathrm{H}\right), 134.9\left(\mathrm{t}, J_{\mathrm{PC}}=5.4 \mathrm{~Hz}, \mathrm{C}_{\mathrm{Ph}}\right), 134.4\left(C_{\mathrm{trz}}-\mathrm{COOEt}\right), 131.9\left(\mathrm{t}, J_{\mathrm{PC}}=28.1 \mathrm{~Hz}, \mathrm{C}_{\mathrm{Ph}}\right), 131.8$ $\left(\mathrm{C}_{\mathrm{Ph}}\right), 129.0\left(\mathrm{t}, J_{\mathrm{PC}}=5.1 \mathrm{~Hz}, \mathrm{C}_{\mathrm{Ph}}\right), 128.5\left(\mathrm{C}_{\mathrm{py}} \mathrm{H}\right), 115.6\left(\mathrm{C}_{\mathrm{py}} \mathrm{H}\right), 63.4\left(\mathrm{OCH}_{2} \mathrm{Me}\right), 43.6\left(\mathrm{NCH}_{3}\right)$, $14.5\left(\mathrm{OCH}_{2} \mathrm{CH}_{3}\right) .{ }^{31} \mathrm{P}\left\{{ }^{1} \mathrm{H}\right\} \mathrm{NMR}\left(121 \mathrm{MHz}, \mathrm{CD}_{3} \mathrm{CN}\right): \delta=-4.7$. HR-MS $\left(\mathrm{CH}_{3} \mathrm{CN}\right): \mathrm{m} / \mathrm{z}$ calculated for $\mathrm{C}_{47} \mathrm{H}_{43} \mathrm{IIrN}_{4} \mathrm{O}_{2} \mathrm{P}_{2}[\mathrm{M}-\mathrm{OTf}]^{+}=1077.1535$; found, 1077.1533 .

Complex 12. From $4 a(5 \mathrm{mg}, 0.004 \mathrm{mmol})$ and $m \mathrm{CPBA}(1.7 \mathrm{mg}, 0.01 \mathrm{mmol})$ in $\mathrm{CD}_{3} \mathrm{CN}(0.4 \mathrm{~mL})$ after $10 \mathrm{~min}$ reaction at room temperature. ${ }^{1} \mathrm{H} \mathrm{NMR}\left(300 \mathrm{MHz}, \mathrm{CD}_{3} \mathrm{CN}\right): \delta=9.35\left(\mathrm{~d},{ }^{3} \mathrm{~J}_{\mathrm{HH}}=5.5\right.$ $\left.\mathrm{Hz}, 1 \mathrm{H}, \mathrm{H}_{\mathrm{py}}\right), 8.06\left(\mathrm{td},{ }^{3} J_{\mathrm{HH}}=8.0 \mathrm{~Hz},{ }^{3} J_{\mathrm{HH}}=1.5 \mathrm{~Hz} 1 \mathrm{H}, \mathrm{H}_{\mathrm{py}}\right), 7.80-7.67\left(\mathrm{~m}, 1 \mathrm{H}, \mathrm{H}_{\mathrm{py}}\right), 7.61\left(\mathrm{~d},{ }^{3} J_{\mathrm{HH}}\right.$ $\left.=8.0 \mathrm{~Hz}, 1 \mathrm{H}, \mathrm{H}_{\mathrm{py}}\right), 7.54-7.44\left(\mathrm{~m}, 4 \mathrm{H}, \mathrm{H}_{\mathrm{ClPh}}\right), 7.42-7.14\left(\mathrm{~m}, 30 \mathrm{H}, \mathrm{H}_{\mathrm{Ph}}\right), 4.10\left(\mathrm{~s}, 3 \mathrm{H}, \mathrm{NCH}_{3}\right), 4.07$ $\left(\mathrm{q},{ }^{3} J_{\mathrm{HH}}=7.2 \mathrm{~Hz}, 2 \mathrm{H}, \mathrm{OCH}_{2} \mathrm{Me}\right), 1.27\left(\mathrm{t},{ }^{3} J_{\mathrm{HH}}=7.2 \mathrm{~Hz}, 3 \mathrm{H}, \mathrm{OCH}_{2} \mathrm{CH}_{3}\right),-16.67\left(\mathrm{t},{ }^{2} J_{\mathrm{PH}}=13.2 \mathrm{~Hz}\right.$, $1 \mathrm{H}, \mathrm{Ir}-\mathrm{H}) .{ }^{31} \mathrm{P}\left\{{ }^{1} \mathrm{H}\right\}$ NMR $\left(121 \mathrm{MHz}, \mathrm{CD}_{3} \mathrm{CN}\right): \delta=6.8$. HR-MS $\left(\mathrm{CH}_{3} \mathrm{CN}\right): \mathrm{m} / \mathrm{z}$ calculated for $\mathrm{C}_{54} \mathrm{H}_{47} \mathrm{ClIrN}_{4} \mathrm{O}_{4} \mathrm{P}_{2}[\mathrm{M}-\mathrm{OTf}]^{+}=1105.2390$; found, 1105.2409 .

Kinetic experiments: Kinetic measurements were performed at $70{ }^{\circ} \mathrm{C}$ in a $300 \mathrm{MHz} \mathrm{NMR}$ spectrometer with the corresponding iridium complex $\left(10 \mathrm{mM}\right.$ in $\left.\mathrm{CDCl}_{3}\right)$ using as internal standard a glass capillary containing the ruthenium phosphine hydride complex $\left[\mathrm{RuH}(\mathrm{CO})(\mathrm{C}, \mathrm{N})\left(\mathrm{PPh}_{3}\right)_{2}\right] \mathrm{OTf}(\mathrm{C}, \mathrm{N}=$ triazolylidene-pyridyl ligand as in complex $\mathbf{4 b}$; Fig. S6) dissolved in $\mathrm{CDCl}_{3}$.

Crystal structure determination. All measurements were made on an Oxford Diffraction SuperNova area-detector diffractometer ${ }^{30}$ using mirror optics monochromated Mo Ka radiation $(\lambda=0.71073 \AA)$ and $\mathrm{Al}$ filtered. ${ }^{31}$ Data reduction was performed using the CrysAlisPro program. The intensities were corrected for Lorentz and polarization effects, and numerical absorption correction based on gaussian integration over a multifaceted crystal model was applied. The structure was solved by direct methods using SHELXT, ${ }^{32}$ which revealed the positions of all not disordered non-hydrogen atoms of the title compound. The non-hydrogen atoms were refined anisotropically. All H-atoms were placed in geometrically calculated positions and refined using a riding model where each $\mathrm{H}$-atom was assigned a fixed isotropic displacement parameter with a value equal to $1.2 \mathrm{Ueq}$ of its parent atom (1.5Ueq for the methyl groups and water). Refinement of the structure was carried out on $\mathrm{F}^{2}$ using full-matrix least-squares procedures, which minimized the function $\Sigma \mathrm{w}\left(\mathrm{F}_{\mathrm{o}}^{2}-\mathrm{F}_{\mathrm{c}}{ }^{2}\right)^{2}$. The weighting scheme was based on counting statistics and included a factor to downweight the intense reflections. All calculations were performed using the SHELXL-2014/733 program. Further crystallographic details are compiled in Tables S2-8. 
Crystrallographic data for all structures have been deposited with the Cambridge Crystallographic Data Centre (CCDC) as supplementary publication numbers 4a (2026204), 4b (2026205), 4c (2026206), 5 (2026207), 6 (2026208), 11 (2026209), and 12 (2026210).

Supporting Information. NMR spectra, kinetic and crystallographic data.

Acknowledgements: We acknowledge generous financial support from the European Research Council (CoG 615653) and from the Swiss National Science Foundation (200020_182663). We thank the group of Chemical Crystallography of the University of Bern for X-ray analysis of all reported structures.

\section{References}

(1) Pearson, R. G. Chem. Rev. 1985, 85, 41.

(2) Ley, M. B.; Jepsen, L. H.; Lee, Y.; Cho, Y. W.; von Colbe, M. B.; Dornheim, M.; Rokni, M.; Jensen, J. O.; Sloth, M.; Filinchuk, Y.; Jørgensen, J. E.; Besenbacher, F.; Jensen, T. R. Mater. Today 2014, 17, 122.

(3) Mohtadi, R.; Orimo, S. Nat. Rev. 2016, 2, 1.

(4) Clapham, S. E.; Hadzovic, A.; Morris, R. H. Coord. Chem. Rev. 2004, 248, 2201.

(5) Bullock, R. M. Chem. Eur. J. 2004, 10, 2366.

(6) Robertson, A.; Matsumoto, T.; Ogo, S. Dalton Trans. 2011, 40, 10304.

(7) Wang, D.; Astruc, D. Chem. Rev. 2015, 115 (13), 6621.

(8) Hassam, M.; Taher, A.; Arnott, G. E.; Green, I. R.; Otterlo, W. A. L. Van. Chem. Rev. 2015, 115,5462 .

(9) Hilt, G. ChemCatChem 2014, 6, 2484.

(10) Labinger, J. A.; Bercaw, J. E. Nature 2002, 417, 507.

(11) Lyons, T. W.; Sanford, M. S. Chem.Rev. 2010, 110, 1147.

(12) Engle, K. M.; Mei, T.; Wasa, M.; Yu, J. Acc. Chem. Res. 2012, 45, 788.

(13) Choi, J.; Macarthur, A. H. R.; Brookhart, M.; Goldman, A. S. Chem. Rev. 2011, 111, 1761.

(14) Wiedner, E. S.; Chambers, M. B.; Pitman, C. L.; Bullock, R. M.; Miller, A. J. M.; Appel, A. M. Chem. Rev. 2016, $116(15), 8655$.

(15) Orimo, S.-I.; Nakamori, Y.; Eliseo, J. R.; Zuttel, A.; Jensen, C. M. Chem. Rev. 2007, 107, 4111.

(16) Olivares, M.; van der Ham, C. J. M.; Mdluli, V.; Schmidtendorf, M.; Müller-Bunz, H.; Verhoeven, T. W. G. M.; Li, M.; Niemantsverdriet, J. W.; Hetterscheid, D. G. H.; 
Bernhard, S.; Albrecht, M. Eur. J. Inorg. Chem. 2020, 2020 (10), 801.

(17) Olivares, M.; Knörr, P.; Albrecht, M. Dalton Trans. 2020, 49 (6), 1981.

(18) Gründemann, S.; Kovacevic, A.; Albrecht, M.; Faller, J. W.; Crabtree, R. H. Chem. Commun. 2001, 4 (21), 2274.

(19) Gründemann, S.; Limbach, H.-H.; Buntkowsky, G.; Sabo-Etienne, S.; Chaudret, B. J. Phys. Chem. A 1999, 103 (24), 4752.

(20) Gründemann, S.; Kovacevic, A.; Albrecht, M.; Faller, J. W.; Crabtree, R. H. J. Am. Chem. Soc. 2002, 124 (35), 10473.

(21) Complex 6 containing -OEt substituent did not show any peculiar bond lengths or angles as observed for the analogous $\mathrm{Cp}^{*}$ complex ${ }^{16}$ which showed an unusually large $\mathrm{Ir}-\mathrm{C}_{\mathrm{trz}}$ distance that is counterbalanced by short $\mathrm{Ir}-\mathrm{Cl}$ and $\mathrm{Ir}-\mathrm{Cp}$ * bonds, as well as a remarkably long $\mathrm{C}_{\mathrm{trz}}-\mathrm{C}_{\mathrm{trz}}$ bond close to that of single bonds (1.472 $\AA$ ). In complex $\mathbf{6}$, this $\mathrm{C}_{\mathrm{trz}}-\mathrm{C}_{\mathrm{trz}}$ distance is $1.380 \AA$, in line with the typically observed conjugated double bond character.

(22) For examples, see: a) Crabtree, R. H.; Mella, M. F.; Mihelcic, J. M. Inorg. Synth. 1990, 28, 56; b) Kaska ; c) Goldberg, J. M.; Goldberg, K. I.; Heinekey, D. M.; Burgess, S. A.; Lao, D. B.; Linehan, J. C. J. Am. Chem. Soc. 2017, 139, 12638.

(23) For examples, see: a) Crabtree, R. H.; Lavin, M.; Bonneviot, L. J. Am. Chem. Soc. 1986, 108, 4032; b) Heinekey, D. M.; van Roon, M. J. Am. Chem. Soc. 1996, 118, 12134; c) Li, X., Appelhans, L. N.; Faller, J. W.; Crabtree, R. H. Organometallics 2004, 23, 3378; d) Appelhans, L. N.; Zuccaccia, D.; Kovacevic, A.; Chianese, A. R.; Miecznikowski, J. R.; Macchioni, A.; Clot, E.; Eisenstein, O.; Crabtree, R. H. J. Am. Chem. Soc. 2005, 127, 16299; e) Chianese, A. R.; Kovacevic, A.; Zeglis, B. M.; Faller, J. W.; Crabtree, R. H. Organometallics 2004, 23, 2461.

(24) Lee, D.-H.; Patel, B. P.; Clot, E.; Eisenstein, O.; Crabtree, R. H. Chem. Commun. 1999, 297

(25) Brereton, K. R.; Smith, N. E.; Hazari, N.; Miller, A. J. M. Chem. Soc. Rev. 2020. doi:10.1039/d0cs00405g

(26) Morris, R. H. J. Am. Chem. Soc. 2014, 136 (5), 1948.

(27) $\mathrm{HNO}_{3}$ was added as a $60 \%$ aqueous solution, which perturbed the homogeneity of the reaction mixture that may account for the observed deviation.

(28) Slightly lower $k_{\text {obs }}$ were obtained from the ${ }^{1} \mathrm{H}$ NMR data compared to the ${ }^{31} \mathrm{P}$ NMR analysis, most likely due to the limited accuracy of integration in the hydride area.

(29) Crabtree, R. H.; Felkin, H.; Morris, G. E. J. Organomet. Chem. 1977, 141, 205.

(30) CrysAlisPro (Version 1.171.34.44). Oxford Diffraction Ltd., Yarnton, Oxfordshire, UK, 2010.

(31) Macchi, P.; Bürgi, H. B.; Chimpri, A. S.; Hauser, J.; Gál, Z. J. Appl. Crystallogr. 2011, $44(4), 763$. 
(32) Sheldrick, G. M. Acta Crystallogr. A 2015, 71 (1), 3.

(33) Sheldrick, G. M. Acta Crystallogr. C 2015, 71, 3.

\section{Hydride references:}

IrH2L2P2]+ Crabtree, R. H.; Mella, M. F.; Mihelcic, J. M. Inorg. Synth. 1990, 28, 56; bq-IrH(H2): trans(PCP)Ir(H)2CO: Goldberg, J. M.; Goldberg, K. I.; Heinekey, D. M.; Burgess, S. A.; Lao, D. B.; Linehan, J. C. J. Am. Chem. Soc. 2017, 139, 12638.

Bbq-NH2:

; Crabtree, R. H.; Lavin, M.; Bonneviot, L. J. Am. Chem. Soc. 1986, 108, 4032; P(P)3IrH2: Heinekey, D. M.; van Roon, M. J. Am. Chem. Soc. 1996, 118, 12134. IrH2LL'P2: Li, X., Appelhans, L. N.; Faller, J. W.; Crabtree, R. H. Organometallics 2004, 23, 3378. IrH2P2(carb)(py): Appelhans, L. N.; Zuccaccia, D.; Kovacevic, A.; Chianese, A. R.; Miecznikowski, J. R.; Macchioni, A.; Clot, E.; Eisenstein, O.; Crabtree, R. H. J. Am. Chem. Soc. 2005, 127, 16299. Chianese, A. R.; Kovacevic, A.; Zeglis, B. M.; Faller, J. W.; Crabtree, R. H. Organometallics 2004, 23, 2461. 
For table of contents entry only:

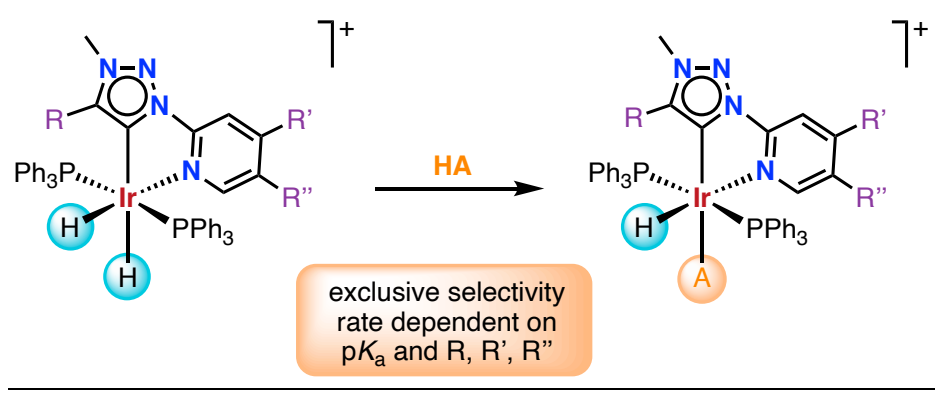

